\title{
The Influence of Geochemistry on Biological Diversity in Fennoscandia and Estonia
}

\author{
Ylo Joann Systra
}

Additional information is available at the end of the chapter

http://dx.doi.org/10.5772/48386

\section{Introduction}

The Earth's crust is predominantly composed of a relatively small number of chemical elements. Only eight of them: oxygen, silicon, aluminum, iron, calcium, magnesium, sodium and potassium are present in amounts exceeding one weight percent and together they comprise almost $99 \%$ of the entire crust $[1,2]$. Some elements are exceedingly rare in the Earth, or have short-lived radioactive isotopes. For example, promethium (Pm) occurs in the crust in only very small concentrations in certain uranium ores, being produced as result of nuclear fission, with the longest-lived isotope having a half-life of only 17.7 years. Similarly, technetium is a relatively light radioactive metal with atomic number 43 , having no stable isotopes, while the longest-lived radioactive isotope (Te-98) has a half-life of 4.2 million years. Technetium only occurs naturally, in trace amounts, in uranium ores produced by nuclear fission [3]. When such elements are excluded, there remain 90 naturally occurring chemical elements [4] to form the geochemical basis of the life of the Earth.

\section{Distribution of chemical elements in the biosphere of the Earth}

The Earth's biosphere is consists of crust, hydrosphere and atmosphere. The Earth's crust is predominantly composed of 9 chemical elements, each having abundances, expressed in atomic weight, of more than one percent: oxygen $(53.39 \%)$, hydrogen $(17.25 \%)$, silicon $(16.11 \%)$, aluminum $(4.80 \%)$, sodium $(1.82 \%)$, magnesium $(1.72 \%)$, calcium $(1.41 \%)$, iron $(1.31 \%)$ and potassium $(1.05 \%)$. The next most abundant elements are: carbon $(0.51 \%)$, titanium $(0.22 \%)$, chlorine $(0.10 \%)$, fluorine $(0.07 \%)$ and sulfur $(0.05 \%)$. Together these 14 elements comprise $99.81 \%$ of the crust in terms of atomic weight, the remaining 76 elements representing only $0.19 \%$ or on average 0.0025 atomic weight percent each [5]. Some of these elements are therefore referred to as rare earth elements (REE). Zinc, copper, nickel, chromium and manganese, which are common in everyday use, also represent trace elements. The 
number of minerals recognized is also in accordance with crustal element abundances. A total of 2909 containing oxygen minerals are known, 1921 minerals contain hydrogen, 906 contain silicon, 714 contain aluminum, 560 minerals contain $\mathrm{Na}, 555$ contain, $\mathrm{Mg}$, 272 contain $\mathrm{K}, 272$ also contain $\mathrm{C}$ and 172 minerals contain Ti. The chemically active elements $\mathrm{Cl}$ and $\mathrm{F}$ occur in 220 and 221 elements respectively. However, due to their greater chemical activity, relatively more minerals have been described containing $\mathrm{Ca}$ (867), Fe (883) and S (761) [5].

There are some differences between mean cosmic abundances and those of the Earth's crust, but the higher abundances of light elements are shared by both environments, implying that the process of nuclide synthesis obeys the same rules. The Oddo-Harkins rule states that for any two neighboring elements, the abundance of the element with an even atomic number is higher than that of the odd one. Of the 28 first elements of Earth's crust the even elements in the periodic table constitute 86.36 weight percents, while odd elements comprise only $13.64 \%$. There are some exceptions from the rule. The noble gases (atomic numbers in brackets): helium (2), neon (10), argon (18), krypton (36), xenon (54) abundances are much lower than precited by the Oddo-Harkins rule, because they have stable nuclei and are chemically inert, and hence do not participate in chemical reactions or form compounds. The noble gases are predominantly present in the atmosphere, with argon abundance being nearly $1 \%$, while the others are present in small amounts, because they can easily escape into space [2].

It must also be noted that especially high abundances are associated with elements for which numbers differ by 6 or multiple 6 and plus 2, such as O (8), Si (14), Ca (20), Fe (26), Sr (38), Sn (50), Ba (60). Of the most abundant elements in the Earth's crust elements, 13 have atomic numbers between 1 and 20, with only iron having a higher number, of 26 [6]. On the diagram of cosmic nuclear abundances plotted against atomic mass numbers, a significant peak indeed appears in the region of iron. This implies that that Earth's core may also contain an abundance of elements of lower atomic number, including iron. The dominance of the lighter elements is easily understood, because less energy is required for the formation. Heavy nuclei have higher electric charges than light nuclei, while for reactions between them also tend to require higher temperatures $[7,8]$.

Chemical elements as a rule are represented by several different isotopes, for which atoms have the same atomic number, but differ in terms of atomic mass. Tin (Sn) has the largest number (10) of naturally occurring stable isotopes, while cadmium and tellurium both have 8 isotopes. Many other elements have from 2-6 isotopes and only 22 elements, including F, $\mathrm{Na}, \mathrm{P}, \mathrm{V}, \mathrm{Mn}, \mathrm{Au}$, have one single stable isotope. The highest isotopic abundances also tend to correlate with those isotopes for, which the atomic mass can be divided by 4 . Oxygen isotopes have the following order of abundance: ${ }^{16} \mathrm{O}-99.76 \%$, odd ${ }^{17} \mathrm{O}-0.04 \%$, even ${ }^{18} \mathrm{O}-$ $0.2 \%$; for silicon, isotope abundances are: ${ }^{28} \mathrm{Si}-92 \%,{ }^{29} \mathrm{Si}-5 \%$ and ${ }^{30} \mathrm{Si}-3 \%$. In the case of carbon isotopes, ${ }^{12} \mathrm{C}$ represents $99 \%$ and ${ }^{13} \mathrm{C}$ about $1 \%$; both of these are non-radioactive, the third isotope ${ }^{14} \mathrm{C}$ is radioactive and occurs in trace amounts in the atmosphere [3].

The 90 naturally occurring elements are found throughout the Earth's crust, in bedrock, groundwater, unconsolidated sediments and soils. More than $70 \%$ of Earth's surface is covered by oceans and seas, which provide habitats and diverse environments for 
numerous species of very different size. One ton of seawater contains the following elements by mass: $\mathrm{Cl}(19.4 \mathrm{~kg}), \mathrm{Na}(10.8 \mathrm{~kg}), \mathrm{Mg}(1,29 \mathrm{~kg}), \mathrm{S}(0.9 \mathrm{~kg}), \mathrm{Ca}(411 \mathrm{~g}), \mathrm{K}(392 \mathrm{~g}), \mathrm{Br}$ (67 g) and 10 trace elements (in order of abundance from 8.1-0.003 g): Sr, B, F, Li, Ru, Ba, I, As and Cs [2]. The composition of atmosphere by volume is: nitrogen (78.09\%), oxygen $(20.95 \%)$, argon $(0.95 \%), \mathrm{CO}_{2}(0.03 \%)$, and neon $(0.0018 \%)$; trace gases are in order of abundance (from 0.0052 to $0.000008 \%$ ): $\mathrm{He}$, methane, $\mathrm{Kr}$, nitrous oxide, $\mathrm{O}_{2} \mathrm{O}_{3}$ and $\mathrm{Xe}$. The abundance of ozone is notable in that it increases with altitude [2].

The biosphere contains innumerable species of plants, animals, fish, birds, insects and other forms of biological life. None of them can exist without water and numerous chemical elements as nutrients.

\section{Chemical elements as nutrients for all forms of biological life}

All plants and animals need a range of different chemical elements as nutrients for normal and healthy growth and development [9]. However, not all of the most widely distributed elements are needed in large amounts. Of the 90 naturally occurring elements on Earth, there are 11 elements found throughout the atmosphere, hydrosphere and within bedrock and soils, that are essential for all plants and animals, namely oxygen, hydrogen, carbon, nitrogen, calcium, magnesium, sodium, potassium, sulfur, phosphorus and chlorine. These elements are also known as macronutrients, of which the first four can be easily obtained from air $(\mathrm{C}, \mathrm{N}, \mathrm{O})$ or water $(\mathrm{H}, \mathrm{O})$, while the remaining 7 elements are more common in bedrock or are present at required concentrations in groundwater. All these elements are essential to life and for example, an adult human requires a daily intake of $100 \mathrm{mg}$ or more of each of these elements [10].

The sources of mineral elements are soils, drinking water and food - each kind of food has its own distinct composition of macro- and micronutrients. For example, phosphorus, calcium, sodium and magnesium are present in every kind of food, but sulfur is usually absent from dried produce [11]. The abundances of the main macronutrients in marine and terrestrial plants, marine and terrestrial animals, and in bacteria (in dry matter) are remarkably similar to one another, which indicate that all forms of living life require the same macro-elements (Table 1).

All macro-biogenic elements are essential for normal life functions and are vital for manufacturing cells and tissues in plants and animals. There is some variation in the actual element abundances according to specific environmental conditions and plant and animal requirements. Terrestrial animals need stronger skeletal support than marine organisms and their proportional abundances of phosphorus and fluorine are consequently 3 and 7 times higher. Other elements, such as potassium, sodium, sulfur and magnesium are more readily available in marine environments than on land and their concentrations in marine plants and animals are accordingly higher. Bacteria do not differ very markedly from other groups, indicating that all life forms on the Earth are essentially composed from the same chemical elements. The human being is not exception, a typical $70 \mathrm{~kg}$ human body consisting of the following major elements: oxygen $(61 \%)$, carbon $(23 \%)$, hydrogen $(10 \%)$, nitrogen $(2.6 \%)$, 
calcium $(1.4 \%)$, phosphorus $(1.1 \%)$, potassium $(0.2 \%)$, sulfur $(0,2 \%)$, sodium $(0.14 \%)$, chlorine $(0.12 \%)$ and magnesium $(0.027 \%)$. However, not all of these widely distributed chemical elements are needed in large amounts by plants and animals. Four elements in particular: silicon, aluminum, iron and titanium, are only required in very small amounts as micro-nutrients for the regulation of specific processes [3].

\begin{tabular}{|l|c|c|c|c|c|c|}
\hline $\begin{array}{l}\text { Macronutrients, } \\
\text { grams in 100 g }\end{array}$ & $\begin{array}{c}\text { Marine } \\
\text { plants }\end{array}$ & $\begin{array}{c}\text { Terrestrial } \\
\text { plants }\end{array}$ & $\begin{array}{c}\text { Marine } \\
\text { animals }\end{array}$ & $\begin{array}{c}\text { Terrestrial } \\
\text { animals }\end{array}$ & Bacteria & $\begin{array}{c}\text { Average of } \\
\text { all groups }\end{array}$ \\
\hline Carbon - C & 34.5 & 45.4 & 40.0 & 46.6 & 54.0 & 44.1 \\
\hline Oxygen - O & 47.0 & 41.0 & 40.0 & 18.6 & 23.0 & 33.7 \\
\hline Hydrogen - H & 1.5 & 3.0 & 7.5 & 10.0 & 9.6 & 6.32 \\
\hline Nitrogen - N & 4.1 & 5.5 & 5.2 & 7.0 & 7.4 & 5.06 \\
\hline Potassium - K & 5.2 & 1.4 & $0.5-3.0$ & 0.74 & 11.5 & 4.12 \\
\hline Calcium - Ca & 1.0 & 1.8 & $0.15-2.0$ & $0.02-8.5$ & 0.51 & 1.44 \\
\hline Sodium - Na & 3.3 & 0.12 & $0.4-4.8$ & 0.4 & 0.46 & 1.38 \\
\hline Phosphorus - P & 0.35 & 0.23 & $0.4-1.8$ & $1.7-4.4$ & 3.0 & 1.29 \\
\hline Sulphur - S & 1.2 & 0.34 & $0.5-1.9$ & 0.5 & 0.53 & 0.75 \\
\hline Magnesium - Mg & 0.52 & 0.32 & 0.5 & 0.1 & 0.7 & 0.43 \\
\hline Chlorine - Cl & 0.47 & 0.2 & $0.5-9.0$ & 0.28 & 0.23 & 0.29 \\
\hline
\end{tabular}

Table 1. Macro-elements content in marine and terrestrial plants and animals, and bacteria (in grams to $100 \mathrm{~g}$ dry matter), modified after Barabanov [12]

The distribution of macro- and micronutrients in different types of bedrock, soils, plants and animals have been studies intensively for more than 50 years, but due to the large ranges in composition, no consensus has been reached on the precise abundances of essential trace element concentrations in living organisms [9-10, 13-22]. The reason for this is that micronutrients are present and needed in very small amounts. For example, selenium is an important microelement for humans but daily intake must not exceed 28-55 $\mu \mathrm{g}$ [22]. The most complete list of micronutrients is given by Emsley [15], which was published on the Internet by Uthman [20]. For an average $70 \mathrm{~kg}$ human body mass the abundances of 59 elements have been determined, including 11 major elements. Of 48 trace elements 43 are considered essential, while the role of thorium, uranium, samarium, beryllium and tungsten is not known. Vanadium is the least abundant biologically necessary element in the human body $(0.11 \mathrm{mg})$ whereas rubidium is the most abundant element in the body $(0.68 \mathrm{~g})$ that lacks any biological role. Silicon $(1.0 \mathrm{~g})$ may or may not have a metabolic function. Only four elements exceed the $1.0 \mathrm{~g}$ level: Fe (4.2 g), F (2.6 g), Zn (2.3 g) and Si (1.0 g), and another four have levels greater than $0.1 \mathrm{~g}$ : $\mathrm{Rb}(0.68 \mathrm{~g})$, $\mathrm{Sr}(0.32 \mathrm{~g}), \mathrm{Br}(0.26 \mathrm{~g})$ and $\mathrm{Pb}(0.12 \mathrm{~g})$. The abundances of the remaining elements fall within the interval between $72-0.11 \mathrm{mg}[15,20]$.

Table 2 shows 29 trace element concentrations in marine and terrestrial plants and animals, and also in bacteria for some elements. The situation with respect to microelements is nearly the same as for major elements. The contents of silicon, iron, zinc, aluminum, rubidium, nickel, cobalt, molybdenum in each group are quite comparable, although some other elements show greater differences in concentration than in the case of macro-nutrients. The abundances of bromine, strontium, iodine, boron, titanium lithium and chromium are 
higher in marine plants and animals, which is to be expected given that sea water contains more of these elements [2] and that uptake from solution is relatively easy. Excess concentrations of many of the trace elements present in soils, including: $\mathrm{As}, \mathrm{Cd}, \mathrm{Co}, \mathrm{Cu}, \mathrm{Cr}$, $\mathrm{Hg}, \mathrm{Mo}, \mathrm{Ni}, \mathrm{Pb}, \mathrm{Se}, \mathrm{Zn}, \mathrm{U}$, Th and $\mathrm{Zn}$, may be toxic to plants and animals or may affect the quality of foodstuff for human consumption [14]. They are potentially toxic to plants and animals, but can have adverse effects at relatively low, insufficient level [21]. In many countries, including Estonia, there are governmental regulations concerning maximum permitted concentrations for toxic and dangerous elements in agricultural lands, industrial and urban environments, and in drinking water.

\begin{tabular}{|l|c|c|c|c|c|c|}
\hline $\begin{array}{l}\text { Microelements, mg } \\
\text { in 100 g dry matter }\end{array}$ & $\begin{array}{c}\text { Marine } \\
\text { plants }\end{array}$ & $\begin{array}{c}\text { Terrestrial } \\
\text { plants }\end{array}$ & $\begin{array}{c}\text { Marine } \\
\text { animals }\end{array}$ & $\begin{array}{c}\text { Terrestrial } \\
\text { animals }\end{array}$ & Bacteria & $\begin{array}{c}\text { Average of } \\
\text { all groups }\end{array}$ \\
\hline Silicon - Si & $150-2000$ & $20-500$ & $7-100$ & $12-600$ & 18 & 342.5 \\
\hline Iron - Fe & 70 & 14 & 40 & 16 & 25 & 33.0 \\
\hline Bromine - Br & 74 & 1.5 & $6-100$ & 0.6 & - & 32.3 \\
\hline Zinc - Zn & 15 & 10 & $0.6-150$ & 16 & - & 29.1 \\
\hline Strontium - Sr & $26-140$ & 2.6 & $2-50$ & 1.4 & - & 28.3 \\
\hline Iodine - I & $3-150$ & 0.042 & $0.1-15$ & 0.043 & - & 21.0 \\
\hline Manganese - Mn & 5.3 & 63 & $0.1-6$ & 0.02 & - & 17.8 \\
\hline Aluminum - Al & 6 & $50(0.05-400)$ & 1.5 & $0.4-10$ & - & 15.7 \\
\hline Fluorine - F & 0.45 & $0.005-4$ & 0.2 & $15-50$ & - & 8.79 \\
\hline Boron - B & 12 & 5 & $2-5$ & 0.05 & - & 5.13 \\
\hline Copper - Cu & 1 & 1.4 & $0.4-5$ & 0.24 & 4.2 & 1.91 \\
\hline Rubidium - Rb & 0.74 & 2 & 2 & 1.7 & - & 1.61 \\
\hline Titanium - Ti & $1.2-8$ & 0.1 & $0.02-2$ & 0.02 & - & 1.43 \\
\hline Barium - Ba & 3 & 1.4 & $0.02-0.3$ & 0.075 & - & 1.16 \\
\hline Arsenic - As & 3 & 0.02 & $0.0005-0.03$ & $\leq 0.02$ & - & 0.76 \\
\hline Nickel - Ni & 0.3 & 0.3 & $0.04-2.5$ & 0.08 & - & 0.49 \\
\hline Lead - Pb & 0.84 & 0.27 & 0.05 & 0.2 & - & 0.34 \\
\hline Tin - Sn & 0.1 & $<0.03$ & $0.02-2$ & $<0.015$ & - & 0.28 \\
\hline Vanadium - V & 0.2 & 0.16 & $0.014-0.2$ & 0.015 & - & 0.21 \\
\hline Silver - Ag & 0.025 & 0.006 & $0.3-1.1$ & $0.0006(?)$ & - & 0.18 \\
\hline Lithium - Li & 0.5 & 0.01 & 0.1 & $<0.002$ & - & 0.15 \\
\hline Cobalt - Co & 0.07 & 0.05 & $0.05-0.5$ & 0.003 & - & 0.099 \\
\hline Selenium - Se & 0.08 & 0.02 & - & 0.17 & - & 0.090 \\
\hline Molybdenum - Mo & 0,045 & 0.09 & $0.06-0.25$ & 0.02 & - & 0.078 \\
\hline Cadmium - Cd & 0.04 & 0.06 & $0.015-0.3$ & $\leq 0.05$ & - & 0.070 \\
\hline Chromium - Cr & 0.1 & 0.023 & $0.02-0.1$ & 0.0075 & - & 0.048 \\
\hline Antimony - Sb & - & 0.006 & 0.02 & 0.0006 & -- & 0.009 \\
\hline Mercury - Hg & 0.003 & 0.0015 & - & 0.0046 & - & 0.003 \\
\hline Tungsten - W & 0.0035 & 0.007 & $0.00005-$ & $?$ & - & 0.0016 \\
\hline
\end{tabular}

Table 2. The content of chemical microelements in marine and terrestrial plants and animals, and bacteria, modified after [12] 
The role of chemical elements in the natural environment first became the subject of study during the early decades of the twentieth century, with the first significant findings emerging in the middle of the century. In some countries, as in Great Britain, the importance of geochemical investigations has been recognized and has been supported by governmentfunded research. The discovery of irregularities in the distribution of diseases in the early 1960 's, particularly with respect to the incidence of cancer in southwest England, initiated a detailed geochemical survey of Britain by a multi-disciplinary research team [23]. Some 20 years later, following numerous international conferences and workshops in environmental geochemistry and health, the main results of investigations were published in a special book [14], which presented for the first time, information concerning all aspects of environmental geochemistry and the distribution of harmful elements in the environment in which people live [23].

Such geochemical studies represent an important component of the environmental and geological research programs in USA, Canada, Australia, Russia, Japan, China, Germany, Poland, Sweden, Norway, Finland and many other countries.

\section{Methods of studying the influence of geochemistry on biodiversity in Fennoscandia and Estonia}

Specialized studies within areas covered by old-growth forests were initiated during the late 1980's in the Republic of Karelia. Much of the forest in this part of the former Soviet Union was intensively logged during the fifty years or so following the $2^{\text {nd }}$ World War. As demand by the forestry and paper industry increased, there was increasing recognition of the need to preserve areas of taiga forest within a network of National Parks. As a result, the bilateral Russian-Finnish project "Inventory and studies of biological diversity in Republic of Karelia" was initiated in 1997-2000 by the Karelian Research Centre of the Russian Academy of Sciences. This project included investigations into bedrock, Quaternary sediments and soil geochemistry, vegetation, forests, mires, fish populations, algal flora and zooplankton, bird fauna, mammals and insect populations in different environments of the Republic of Karelia, with particular emphases on areas of high nature conservation value [24]. The author of the current paper was involved in the project as a geologist and as a result of 30 years experience, is familiar with bedrock composition and geochemistry in all kinds of terrain. Fieldwork during the years 1962-1984 in North Karelia and another parts of Karelia principally comprised many thousand kilometers of geological traverses on foot, from the White Sea to Russian-Finnish border, where significant areas of old growth forest remained [Figure 1].

The research group at the Karelian Research Center of Russian Academy of Sciences was characterized by close collaboration between specialists in different fields, including forestry, vascular plants, mosses, lichens, mammal species, bird fauna, insects, algal flora, periphyton-, zooplankton-, macrozoobenthos-, and fish communities. The interactions between these specialists during the field studies resulted in much new information being obtained and published at first in Russian, as progress reports of field studies, and finally in 
Russian and English. The final report [24] provides extensive material for researchers in widest wide range of ecological and biological fields. Geological reviews of the Karelian Region and more detailed local studies, with numerous chemical analysis of bedrock have been published in Systra [27-36] and in [37]. The general geochemical characteristics for soils in the Republic of Karelia were published by Fedorets et al. [38], while a geochemical study of the bedrock of Valaam Island, Lake Ladoga, was done by Sviridenko and Svetov [39], forest litter and underlying mineral material were studied by Shiltsova et al. [40], and the distribution of vascular plants in Republic of Karelia was reported by Kravchenko et al. [41].

Detailed fieldwork was done in the Onega Synclinorium and the central part of the Zaonezhje Peninsula, the Paanajärvi National Park, and along the western and northwestern shore of Lake Ladoga. The results of previous research also facilitated characterization of the Western White Sea area and Central Karelia. Later, in 2002-2003 and 2008-2009, LAPBIAT and LAPBIAT-2 financial support made it possible to visit key areas for studying the influence of bedrock geochemistry on vegetation in subarctic Lapland in Finland, in the surroundings of Kilpisjärvi and Kevo, and in the Oulanka National Park, Kuusamo. The influence of carbonate rocks on vegetation in the Kilpisjärvi Region in Lapland, at latitude $69^{\circ} \mathrm{N}$, was already noted by Pesola [42] at the beginning of the last century, leading to the creation in 1916 of the first protected area in Finland (now Malla Strict Reserve). Subsequently, in 1956, the Oulanka River valley near the Arctic Circle, the Oulanka National Park was declared. On the Russian side of the border the Paanajärvi National Park is larger still (1040 sq. km) and was created in 1992. The geochemical control of vegetation type is clearly marked, especially in the old forests, which are in near pristine condition and the chemical composition of bedrock is well studied. A comprehensive description of the bedrock of Finland is given in Lehtinen et al. [43, 44] and bedrock chemical characteristics in Rasilainen et al. [45].

The composition of bedrock and soils in Estonia are also well studied [46-49]. Environmental protection and the study of vegetation, birds and mammals has has a history extending back more than 100 years. Based on data from about 1550 analyzed samples, the geochemical atlas of the humus horizon of Estonian soils was prepared by Petersell et al. [49]. The 33 geochemical maps in this study, and the "Atlas of Estonian Flora" with 1353 species maps of vascular plant distribution [50] was used for accessing the influence of bedrock on vegetation.

The area considered here embraces the eastern part of Fennoscandian Shield from Kilpisjärvi and Halti Mountain and Kevo in Finnish Lapland $\left(69^{\circ} 45^{\prime} \mathrm{N}\right)$ to northern and northwestern Ladoga Lake $\left(61^{\circ} 15^{\prime} \mathrm{N}\right)$ and Estonia $\left(59^{\circ} 40^{\prime}-57^{\circ} 30^{\prime} \mathrm{N}\right)$. The ancient shield is represented geologically by crystalline metamorphic and igneous bedrock of Archean and Early Proterozoic ages. In Estonia these crystalline rocks are completely covered by Late Proterozoic and Paleozoic sedimentary rocks. Crystalline and sedimentary rocks differ in their respective physical and mechanical properties, and chemical composition [2]. The geology of Finland is well known and covered by comprehensive geological and geochemical maps [25-26, 45]. 


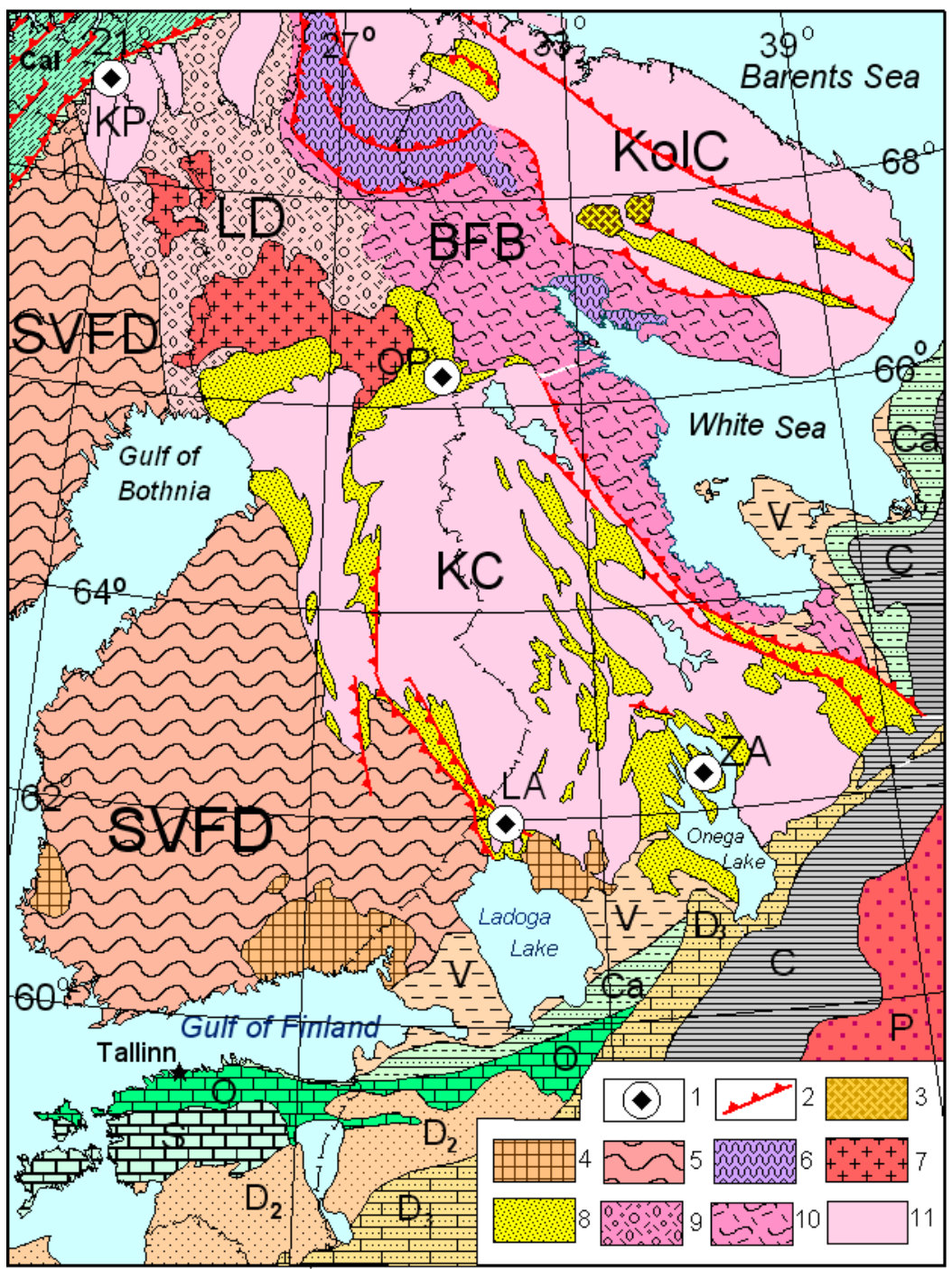

Legend: 1 - Places of detailed study: KP - Kilpisjärvi, OP - Oulanka-Paanajärvi area, ZA - Zaonezhje peninsula, Onega synclinorium, LA - northwest Ladoga Lake shore. 2 - thrusts; 3 - Devonian nepheline syenite; 4 - rabakivi granites; 5 Svecofennian folded domain (SVFD); 6 - Lapland-Belomorian Granulite Belt; 7 - Kemijärvi granites.

Early Proterozoic volcanic-sedimentary rocks: 8 - Lapland Domain (LD); 9 - cover on the Archean basement. Archean: 10 Belomorian Fold Belt (BFB); 11 - Archean cratons: Kola Craton (KolC) and Karelian Craton (KC).

Neoproterozoic-Paleozoic sedimentary cover (from youngest): P - Permian and younger rocks:

C - Carbon (carbonate rock, coal, clay, sandstone); $\mathrm{D}_{3}$ - Upper Devonian (carbonate rocks, sandstone, clay); $\mathrm{D}_{2}-\mathrm{Middle}$ Devonian (sandstones); Cal - thrusted Scandinavian Caledonides; S and O - Silurian and Ordovician (carbonate rock, oil shale); $\mathrm{Ca}$ - Cambrian (sandstone, claystone); Ediacaran, Vendian complex (arkose, sandstone, claystone).

Figure 1. Geological map of the eastern part of Fennoscandian Shield and northwest marginal zone of the Russian Platform. Compiled by Y.J.Systra with using geological map of Finland [25] Fennoscandia [26] and unpublished author's map „Tectonics“, Karelia (1996). 
For all of the areas studied, sufficient data were available concerning bedrock chemical composition. In the Onega region some 20 complete and partial soil profiles were analyzed for major and trace element chemistry, including sampling from both bedrock and soil horizons, in order to quantitatively assess the influence of bedrock on soil composition. Geochemical data were carefully compared with the distribution of each group of plant and animal distribution; for rare and endangered species the Red Data books of Eastern Fennoscandia [51] and the Republic of Karelia [52] were useful.

Comparisons between geochemistry in different environments and the diversity of vegetation and, especially with the distribution of rare and protected plants, showed that biodiversity is influenced by different geological and geographic features, such as latitude and its solar aspect, relief and orientation of landforms, the presence of fault zones as conduits for mineralized groundwater and springs, the color of exposed bedrock and the presence of migration corridors. Nevertheless, the main control on biodiversity is usually geochemical, where the bedrock and overlying regolith contains an abundance of essential macro- and micronutrients. The Fennoscandian Shield and the surrounding Russian Platform marginal zone with its 150-700 m thick sedimentary cover sequence is an excellent area for studying the interdependence of geochemistry and biological diversity. Extensive areas have never been used for agriculture and many are currently protected from commercial exploitation. The biodiversity of the region is also relatively young, in that the continental ice sheet last withdrew from Southern Estonia between 13 500-11 700 years ago, and from northern Fennoscandia between 9000-6500 years ago. Indeed, natural exchange and colonization plants and animals, especially birds, between Oulanka National Park, (Finland) on the western side of the Maanselkä topographic divide and Paanajärvi National Park in Russian Karelia to the east, is continuing to the present day.

\section{Results}

The results of the study are presented separately for each region, because their geological and geochemical conditions are very different. The Republic of Karelia, in the Russian Federation, has a total area of $172400 \mathrm{~km}^{2}$ [53], and occupies the southeastern part of the Fennoscandian Shield. The Karelian part of the Shield comprises 3 major northwesterly trending geological domains, the Karelian Craton in the centre, the Archean Belomorian fold belt to the northeast and the Svecofennian fold terrane to southwest [35]. The exposed part of the Karelian Craton is about $600 \mathrm{~km}$ long and $300 \mathrm{~km}$ wide, with the southeastern edge being covered by Late Proterozoic Ediacaran and Paleozoic sedimentary rocks, which are contiguous with those in Estonia. The Karelian Craton formed during two distinct orogenic events, the first of which is represented by the Archean (3.8-2.5 Ga) basement, composed of Paleoarchean gneiss, gneissose diorite and migmatites, and narrow Meso- and Neoarchean greenstone belts, consisting of volcanic-sedimentary rocks. The younger phase of evolution of the craton is recorded by Paleoproterozoic (2.5-1.8 Ga) volcanic-sedimentary sequences which are preserved in synclinorial structures. The Archean and Proterozoic rocks differ greatly in geochemical characteristics: basement granites and migmatites are rich in $\mathrm{SiO}_{2}$, but contain only very small amounts of micronutrients, while Paleoproterozoic rocks are 
more diverse in composition, including many types of volcanic rocks, sandstone, quartzite, carbonate rocks, and shungite-bearing black schists (Figure 2). The areas selected for detailed study in the Republic of Karelia were in the Paanajärvi national park near the Arctic Circle, supplemented by brief studies in the adjoining Oulanka National Park in Finland the northwestern shoreline of Lake Ladoga, focusing on the influence of the Mesoproterozoic Valaam gabbro-dolerite sill on soil composition and vegetation, and the Onega Synclinorium, each of which represent Paleoproterozoic bedrock having favorable compositions for supporting diverse vegetation.

Estonia is geologically situated on the northwest margin of the East-European Platform, where the Precambrian crystalline basement is covered by Ediacaran and Paleozoic sedimentary cover, varying in thickness from $120-150 \mathrm{~m}$ in northern Estonia to $500-780 \mathrm{~m}$ in southern parts of the country. The basement surface and all sedimentary cover layers are tilted gently southwards at a gradient of nearly 2.5-3 m per kilometre. Cambrian, Ordovician and Silurian sediments are exposed in Northern Estonia as east-west trending belts, whereas to the south these older sequences are covered by younger Middle and Late Devonian deposits. As everywhere in Fennoscandia the bedrock is usually covered by a thin veneer of Quaternary soft sediments, which contain material derived from both local bedrock as well as clasts transported from the crystalline bedrock of Finland and Sweden. Accordingly, since the southern marginal zone of the Fennoscandian shield is represented mostly by migmatites and gneisses, more than $90 \%$ of the transported glacial deposits consist of granitic material. This in turn has an influence on soil composition and vegetation in Estonia.

\section{Paanajärvi-Oulanka protected reserves}

Conservation areas near the Arctic Circle $\left(66^{\circ} 10^{\prime}-66^{\circ} 30^{\prime} \mathrm{N}\right)$ include two significant and contiguous national parks straddling the national borderline between Finland and Russia. The older and smaller Oulanka National Park $\left(277.2 \mathrm{~km}^{2}\right)$ was established in Finland in 1956, while the larger Paanajärvi National Park $\left(1045 \mathrm{~km}^{2}\right)$ in Russian Karelia was declared in 1992. Both parks share similar geological features and vegetation types. The PaanajärviOulanka area has a significantly higher level of biodiversity compared to surrounding areas, due to a combination of mountainous terrain, the east-west orientation of deep valleys, microclimate and distinctive bedrock composition (Table 3).

Paleoarchean basement gneisses and granites (Table 3, No 2906, No 2969) are rich by $\mathrm{SiO}_{2}$, but contain limited amounts of $\mathrm{Mg}$ and $\mathrm{Ca}$ and biologically needed micronutrients and (Figure 2). Small metamorphosed Meso- and Neoarchean ultramafic bodies (Table 3, No 2957-2) and thin komatiite layers between basalts contain appropriate microelements, but have very restricted distribution and do not significantly influence soil composition. The nutrient richness of soils is instead due to the Paleoproterozoic intermediate, acid, mafic, ultramafic volcanic rocks and different types of sedimentary rocks, including dolomite marbles and carbon-rich black schist. Effusive rock types such as felsic quartz porphyry (Table 3, No 3299) also contains higher concentrations of the trace metals $\mathrm{Ti}, \mathrm{Fe}, \mathrm{K}, \mathrm{Ba}, \mathrm{Mn}$ and $\mathrm{V}$ than granites. Intermediate basaltic andesite (Table 3, No 3319) has still higher abundances of $\mathrm{Fe}, \mathrm{Mg}, \mathrm{Ca}, \mathrm{Co}, \mathrm{Cr}, \mathrm{Cu}$ and Ni. The mafic volcanic diabase (Table 3, No 2932-3) and leucogabbro (Table 3, No 3337) have similar 
compositions, although there are some differences in macro-element abundances; both rock types nevertheless contain adequate amounts of necessary microelements. Because mafic volcanic rocks are widely distributed in both national parks, there is no deficiency in microelements in the region. Although conglomerates (Table 3, No 2942) and quartzites (Table 3, No 3167-10) are $\mathrm{SiO}_{2}$-rich, they nevertheless contain some $\mathrm{Co}, \mathrm{Cr}, \mathrm{Mn}, \mathrm{Ni}$ and V. Quartzite sampled from a fault zone is brecciated and mineralized with fuchsite $(\mathrm{Cr}), \mathrm{Ca}, \mathrm{Ba}$ and carbonates, as indicated by the higher weight losses on ignition (LOI) and Ca abundances. The dominant source of $\mathrm{Mg}$ and $\mathrm{Ca}$ in soil is dolomitic marble (Table 3 No 2944), which is common throughout the bedrock of the area and consists of about $95 \%$ dolomite $(\mathrm{Ca}, \mathrm{Mg}) \mathrm{CO}_{3}: \mathrm{CaO}$ $32.22 \%, \mathrm{MgO} 19.51 \%$ and $\mathrm{CO}_{2} 43.12 \%$ (LOI).

All of the above-mentioned rock types are well represented in Quaternary glacial and glaciofluvial deposits, as glacial erosion for some 50-60 km along the deep Oulankajoki River-Paanajärvi Lake-Olanga River valley was entirely within bedrock of the Paleoproterozoic volcanic and sedimentary cover sequence. Fragments of marble are common in till and fluvioglacial sediments everywhere in the studied area, their influence on soil composition can be observed some $\mathrm{km}$ to east, outside of the Paanajärvi syncline, in areas underlying by Archean basement (Figure 2).

This favorable soil composition is the main reason for the unusual biological diversity of the Paanajärvi-Oulanka national parks. About 600 species of vascular plants have been identified, 67 of which have never have been reported from other parts of Karelia [24, 30]. There are 298 species of, 42 of which are listed in the Red Book of Karelia [52], while 443 species of lichen species have been recorded [56], of which $10 \%$ are rare or endangered. This number of taxa represents twice that of the corresponding figure for surrounding terrain. The Oulanka and the Paanajärvi national parks are underlain by Paleoproterozoic (2.5-1.9 Ga) volcanic and sedimentary rocks - including carbonates, while the bedrock in the surrounding region consists of diorites, granites and gneisses of the Karelian Craton [27-30, 35].

The mountainous nature of the terrain, including the higher peaks, which are over $450 \mathrm{~m}$ high and lie above the tree line, means that the area lies within the mountain tundra belt. Alpine-Arctic vegetation, including Loiseleuria procumbens L., Phyllodoce caerulea (L.) Bab., Diphasiastrum alpinum L. and other species is present on the highest mountains Nuorunen (576 m), Mäntytunturi (550 m) and Kivakka (499.5 m). Along the Kiutaköngäs rapids in the Oulanka River valley, a relict community of Dryas octapetala L. has survived since the Ice Age, together with Calipso bulbosa L. In contrast, there are no more than 30-35 species of more northerly affinity. On the Paleoproterozoic volcanic and sedimentary rocks, soli acidity is near-neutral, and soils are enriched in all essential trace elements. Bedrock geochemistry is the main reason for the high biological diversity here, principally due to the presence of carbonate rocks; the dolomitic marbles are responsible for buffering the neutral soil composition. Most occurrences of Cypripedium calceolus L. (Lady's Slipper) are confined to carbonate rock exposures, where up to 2000 individuals may be found an area of some hundred square meters. Slope aspect and exposure also has a marked effect on microclimate. Thus, southerly species inhabit south-facing slopes and deep valleys which show a greenhouse effect, whereas northern species persist under favorable conditions on cold north-facing slopes and in deep shady valleys. 


\begin{tabular}{|c|c|c|c|c|c|c|c|c|c|c|}
\hline Component & 2906 & 2969 & $2957-2$ & 3299 & 3319 & $2932-3$ & 3337 & 2942 & $3167-10$ & 2944 \\
\hline $\mathrm{SiO}_{2}$ & 69.66 & 74.64 & 44.74 & 69.40 & 55.00 & 50.46 & 51.10 & 84.64 & 85.36 & 3.54 \\
\hline $\mathrm{TiO}_{2}$ & 0.27 & 0.10 & 0.29 & 0.77 & 0.65 & 0.73 & 0.43 & 0.10 & 0.12 & 0.04 \\
\hline $\mathrm{Al}_{2} \mathrm{O}_{3}$ & 15.19 & 14.67 & 6.90 & 12.86 & 13.00 & 14.84 & 16.26 & 8.40 & 2.80 & 0.26 \\
\hline $\mathrm{Fe}_{2} \mathrm{O}_{3}$ & 0.60 & 0.18 & 4.22 & 2.29 & 2.40 & 3.51 & 1.47 & 0.77 & 0.23 & 0.17 \\
\hline $\mathrm{FeO}$ & 2.15 & 1.01 & 7.90 & 3.23 & 7.54 & 9.05 & 5.60 & 0.21 & 0.73 & 0.93 \\
\hline $\mathrm{MgO}$ & 1.31 & 0.45 & 25.60 & 0.50 & 7.10 & 8.80 & 7.60 & 1.35 & 0.30 & 19.51 \\
\hline $\mathrm{CaO}$ & 1.82 & 1.96 & 4.28 & 1.96 & 7.43 & 6.09 & 11.43 & 0.14 & 4.76 & 32.22 \\
\hline $\mathrm{K}_{2} \mathrm{O}$ & 2.66 & 0.93 & 0.03 & 4.19 & 2.13 & 0.85 & 1.52 & 2.86 & 0.79 & 0.05 \\
\hline $\mathrm{Na}_{2} \mathrm{O}$ & 5.00 & 5.45 & 0.13 & 3.50 & 2.50 & 2.53 & 2.15 & 0.03 & 0.02 & 0,03 \\
\hline $\mathrm{P}_{2} \mathrm{O}_{5}$ & - & - & 0.06 & - & - & 0.124 & - & 0.072 & - & - \\
\hline$S$ & 0.01 & 0.04 & - & - & - & 0.02 & - & 0.01 & - & 0.04 \\
\hline LOI & 0.61 & 0.26 & 5.08 & 0.67 & 1.61 & 2.54 & 2.00 & 1.10 & 3.83 & 43.12 \\
\hline $\mathrm{Ba}$ & 536 & 626 & - & 1584 & 806 & - & 985 & - & 4475 & - \\
\hline Co & 20 & 20 & - & - & 63 & 63 & 55 & 16 & - & - \\
\hline $\mathrm{Cr}$ & 109 & 146 & 796 & 78 & 260 & 135 & 114 & 104 & 598 & - \\
\hline $\mathrm{Cu}$ & 16 & 8 & - & - & 64 & 32 & 24 & 8 & - & - \\
\hline Mn & 349 & 202 & 1550 & 891 & 1550 & 837 & 1085 & 39 & 202 & 1465 \\
\hline $\mathrm{Ni}$ & 20 & 20 & 632 & - & 95 & 150 & 142 & 39 & - & 102 \\
\hline V & 31 & 10 & 78 & 62 & 47 & 125 & 292 & 31 & 61 & - \\
\hline $\mathrm{Li}$ & - & - & - & 35 & 39 & - & 10 & - & - & - \\
\hline $\mathrm{Rb}$ & - & - & - & 71 & 66 & - & 22 & - & - & - \\
\hline Zn & - & - & - & 146 & - & - & - & - & - & -- \\
\hline
\end{tabular}

Table 3. Chemical composition of bedrock in the North-Karelian synclinal zone in Russia (represents the Oulanka-Paanajärvi parks area). Analyses from Systra [27, 28]. Macro-element oxides in weight \% (sulphur as element), microelements in ppm, analyses made in Laboratory of Institute Geology, Karelian Research Centre, Russian Academy of Sciences. (-) component not analyzed, Archean bedrock: No 2906 - biotite gneiss, No 2969 - gneissose plagiogranite, No 2957-2 - metapyroxenite.

Paleoproterozoic bed-rock: No 3299 - quartz porphyry, No 3319 - andesitic basalt, No 2932-3 - diabase, No 3337 - leucogabbro, No 3167-10 - quartzite with fuchsite from fault zone, No 2942 - Proterozoic basal quartz rich conglomerate, No 2944 - dolomite marble 


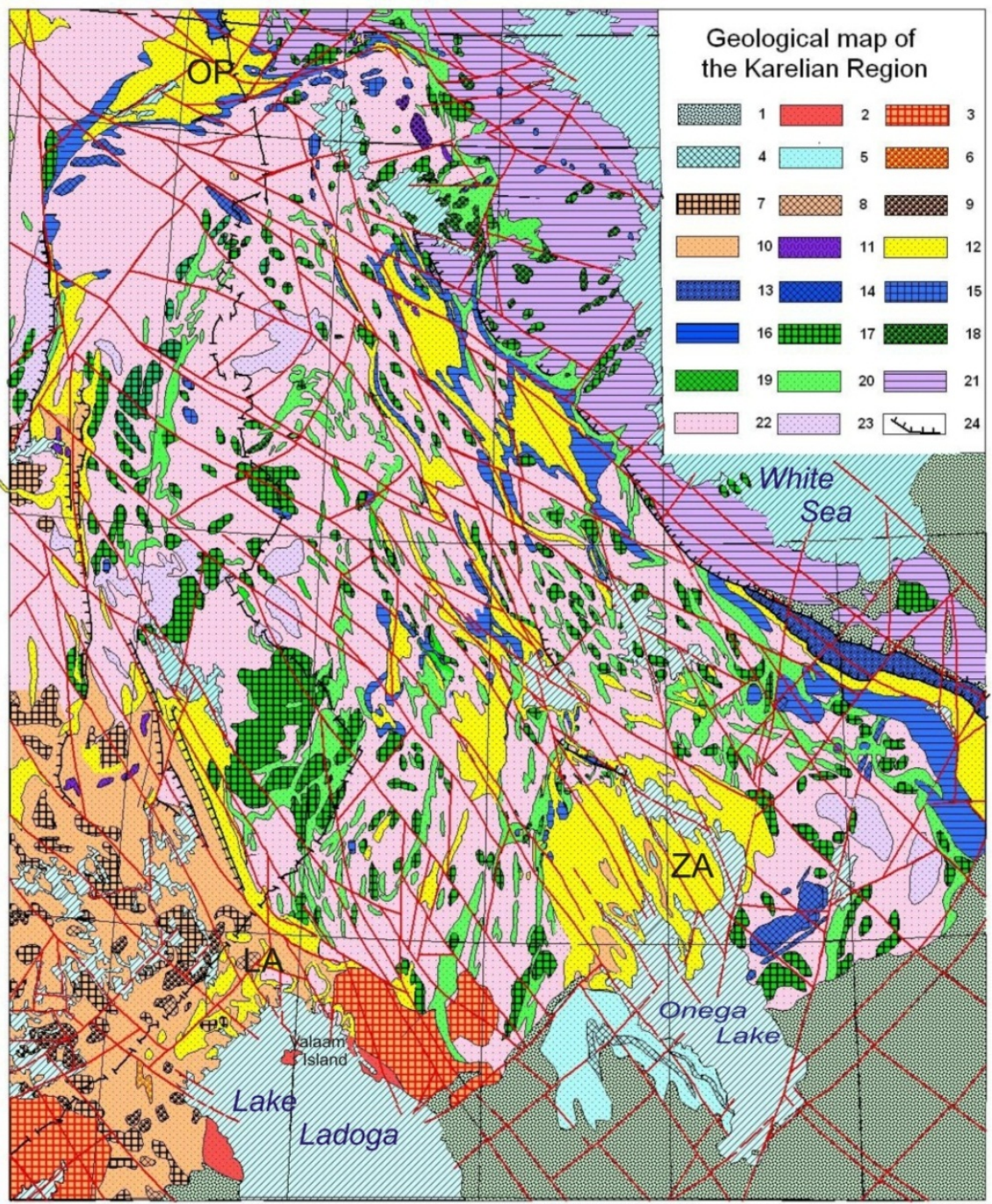

Legend: Post-Svecofennian bedrocks: 1 - Ediacara-Paleozoic platform cover; 2 - Ladoga aulacogene; 3 - post-orogenic rabakivi granites; 4 - Vepsian dolerite sills; 5 - Vepsian sedimentary rocks. Rocks of the Svecofennian (1.92-1.77 Ga): alkaline diorites and gabbro; 7 - granites; 8 - gabbro; 9 - diorites; 10 - Kalevian volcanic-sedimentary rocks; 11 - 1.98 1.95 Ga ultramafic rocks; 12 - Ludicovian and Jatulian sedimentary and volcanic rocks, including carbonates. Sumian and Sariolian (2.5-2.3 Ga) bedrocks: 13 - komatiitic basalts; 14 - layered mafic-ultramafic rocks; 15 - paligenetic granites; 16 - sedimentary-volcanic bedrocks. Neo- and Mesoarchean (2.6-3.0 Ga) bedrocks: 17 - granites; 18 - diorites; 19 - gabbro; 20 - sedimentary-volcanic rocks of greenstone belts; 21 - Belomorian Foded Belt, undivided. The oldest rocks in the region: 22 - basement granitic gneisses in the Karelian Craton; 23 - relics of the oldest sedimentary and volcanic sequences; 24 - thrust zones. Red lineaments: the main fault zones of Karelian Region. The places of study the bedrock geochemistry influence to vegetation: $\mathrm{OP}$ - Oulanka-Paanajärvi national parks are with surrounding territory; ZA - Zaonezhje Peninsula in the Lake Onega; LA - northeastern shore area of the Lake Ladoga and Valaam Island.

Figure 2. Geological map of the Karelian Region. Compiled by Y.J.Systra with using geological maps of Finland [25], Fennoscandia [26] and author's unpublished map "Tectonics, Karelia"(1996). 

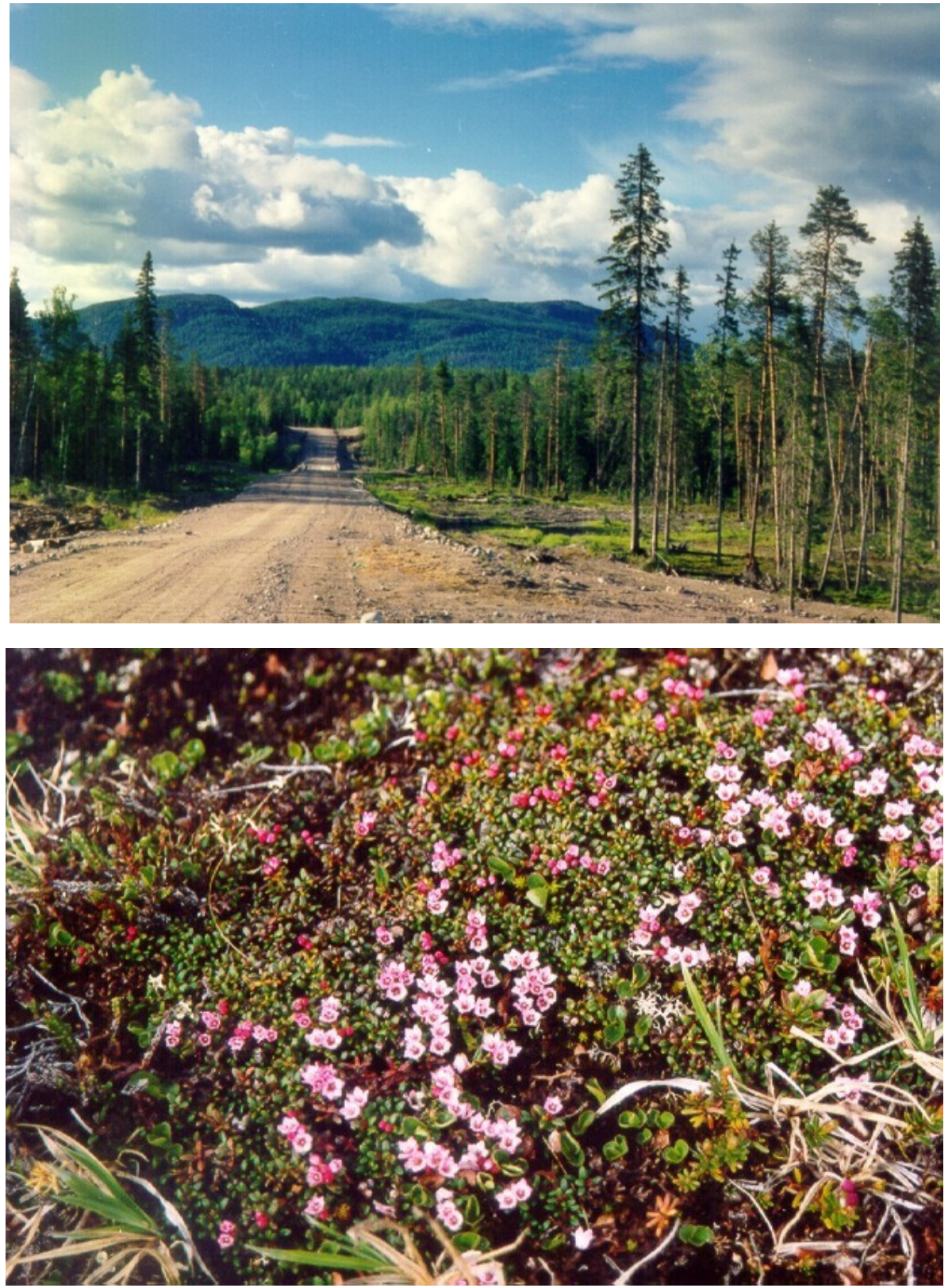

Figure 3. On left Kivakka Hill ( $499.5 \mathrm{~m}$ ) in the Paanajärvi NP presents one the best layered peridotitegabbronorite massifs in Europe. Strong bedrock from magma is not eroded so quickly as surrounding gneisses and diorites. On the top is developed mountain tundra zone with typical vegetation. On the photo below is flowering one of protected northern species - Loiseleuria procumbens L. On the southern slope of hill found places for nesting some southern species of birds 
Numerous springs occur on the deep valley slopes, with discharge rates usually about 0.2-3 $\mathrm{L} / \mathrm{s}$. The chemical composition of groundwater in the upper vadose zone above the watertable is determined principally by topographic relief. In the eastern part of Paanajärvi, the summits of the hills are at 305-342 m above sea level, which is from 100-185 m above the level of lakes and rivers, which lie at elevations between 136-208 m [55]. Groundwater infiltrates bedrock to some extent, yielding ultra-fresh hydro-carbonate-Ca waters, with very low mineral contents, less than $100 \mathrm{mg} / \mathrm{L}$. The temperature of spring water is $3.5-4.2^{\circ} \mathrm{C}$, and $\mathrm{pH}$ is within the range 7.39-6.76. Although the chemical components occur at very low concentrations in spring waters, the cumulative annual flux can be considerable, even at relatively low discharge rates. This is illustrated by calculations for spring no. 6 (discharge rate $=0,5 \mathrm{l} / \mathrm{s}$ and (spring no. 9 (discharge rate $=0.3 \mathrm{l} / \mathrm{s}$ ) respectively: macro-elements $\mathrm{Ca}$ (216 and192 kg), $\mathrm{SO}_{4}{ }^{2-}(86.7$ and $54.6 \mathrm{~kg}), \mathrm{MgO}(34.7$ and $14.2 \mathrm{~kg}), \mathrm{Na}(22$ and $18 \mathrm{~kg}), \mathrm{K}(17.3$ and $10.4 \mathrm{~kg}), \mathrm{PO}_{4}{ }^{3-}(0.47$ and $0.19 \mathrm{~kg}), \mathrm{NO}_{3^{-}}(0.63$ and $0,095 \mathrm{~kg}), \mathrm{Cl}(11$ and $6.6 \mathrm{~kg})$ and microelements: F (2 and $1.8 \mathrm{~kg}), \mathrm{Fe}(0.93$ and $1.2 \mathrm{~kg}), \mathrm{Zn}(1.2$ and $0.32 \mathrm{~kg}), \mathrm{Al}(140$ and $643 \mathrm{~g})$, Ba (227 and $457 \mathrm{~g}$ ), Sr (219 and $304 \mathrm{~g}$ ), Mn (14.7 and $45.5 \mathrm{~g}$ ), I (22 and $12.3 \mathrm{~g}$ ), Cr (8.4 and 8.5 g), V (9.6 and $2.9 \mathrm{~g}), \mathrm{Ni}$ (3.9 and $2.4 \mathrm{~g}), \mathrm{Cu}(8.5$ and (6.0 g), Co (0.6 and $0.6 \mathrm{~g})$, Se (14.9 and $0.95 \mathrm{~g}), \mathrm{Sb}$ (10.1 and $4.7 \mathrm{~g}$ ), Cd (0.16 and $7.8 \mathrm{~g}$ ), Pb (2 and $15.3 \mathrm{~g}), \mathrm{Hg}$ (1.9 and $0.28 \mathrm{~g}$ ), As (0.47 and $0.47 \mathrm{~g}$ ) [57]. Small mires often form near springs, typically covering an area of several hundred square meters. Some of the water discharge is through capillary flow and in vapour phase, further enriching the soil in nutrients required by vegetation. It is only in such mires, with cold water, that cold-resistant calciphilous species are found, such as: Saxifraga hirculus L., Epilobium davuricum Hornem., E. alsinifolium Vill., Angelica archangelica ssp. norvegica (Rupr.) Nordh., Juncus triglumis L.

One prominent cliff section - Ruskeakallio (= Brown Cliffs) on the northern shore of lake Paanajärvi, composed by albitite dyke with numerous carbonate veins, is about $60 \mathrm{~m}$ high and more than $300 \mathrm{~m}$ long. This vertical sunny wall with hanging gardens is unique, with its botanical rarities including Gypsophila fastigiata L.,Aspenium ruta-muraria L., Draba cinerea Adams, D.hirta DC, Potentilla nivea L., Androsace serpentronalis L., Hackelia deflexa (Wahlenb.) Opiz and more than 20 additional rare plants. During the last 150 years many generations of famous Scandinavian, and after the last war, Russian botanists have visited the Ruskeakallio cliffs. Now it is one of the most picturesque destinations in the Paanajärvi National Park, although it is not permitted to set foot on the shore, in order to protect the unique vegetation. The Paanajärvi National Park is also the only locality in Eastern Fennoscandia from which the lichen Usnea longissima Ach. has been recorded during the last 50 years [51,56]. A total of 97 vascular plants present at Paanajärvi have been listed in Red Book of Karelia [52]. One of the indications that the soils at Paanajärvi are compositionally favorable is the abundance of old spruce forest, which covers more than $60 \%$ of the terrain. Pine forests prevail on the coarse-grained glaciofluvial Quaternary gravels in the Oulankajoki River and Olanga River valleys, which formed through the action of very powerful melt-water-streams [32] during melting of the last ice sheet, about 10000 years ago. 

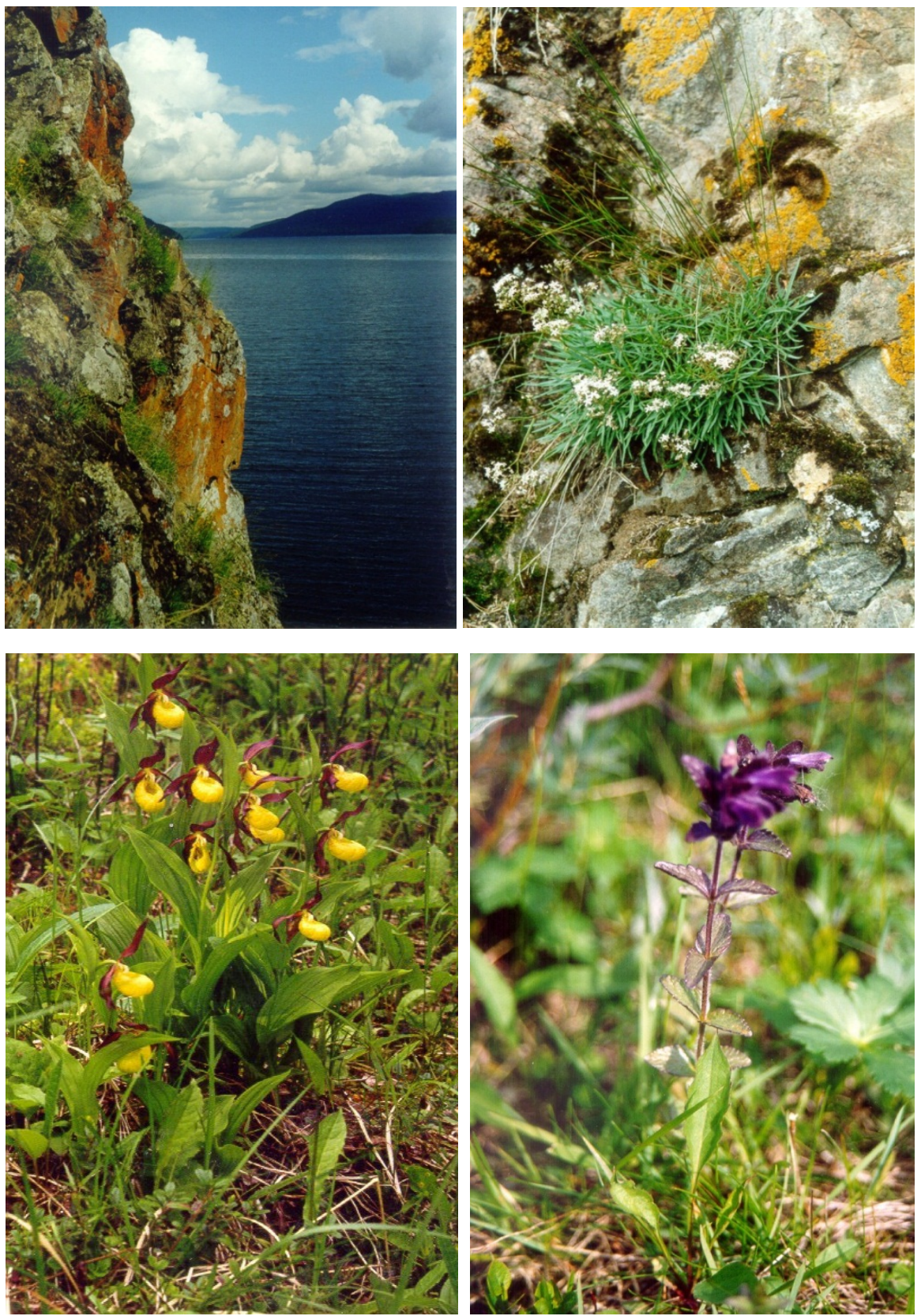

Figure 4. Ruskeakallio (Brown Cliff) is $60 \mathrm{~m}$ high vertical wall with unique vegetation (above left). One of very rare plant Gypsophila fastigiata L. (above right). Lady's slipper (Cypripedium calceolus L.) is common in both Oulanka and Paanajärvi National Parks (below left). Bartsia alpina L. - common plant for Paanajärvi and Oulanka (below right). 
The deep valley of the containing Lake Paanajärvi and through which the Oulankajoki River flows has been incised into the Maanselkä Uplands, the highest points of which are between 400-600 m above sea level. This rugged topography has given rise to a special migration corridor at $109 \mathrm{~m}$ above sea level on Lake Pääärvi to elevations of $200 \mathrm{~m}$ above sea level along the western border of the Oulanka National Park. Over the last 20 years a number of new species of birds and plants have been found on both sides of the Maanselkä topographic divide. Lake Paanajärvi has a maximum depth of $128 \mathrm{~m}$, and its deepest part is thus only $8 \mathrm{~m}$ above the mean level of the White Sea. Nevertheless, at no stage during its history has Lake Paanajärvi been in contact with the White Sea, and the lake is inhabited by relict populations of smelt, sea trout, arctic char, whitefish, grayling and other typical Karelian lacustrine fishes. The small crustaceans Mysis, Monoporeia and Pallacea provide an important food source for valuable fish species.

Favorable geochemistry, hilly relief, and soils and floral diversity also contribute to the unusual diversity of birds, animals, fishes and insect species for this the latitude near the Arctic Circle.

\section{Onega Synclinorium and Zaonezhje peninsula}

Onega Synclinorium in one of the largest Paleoproterozoic structural features preserved in the Karelian Craton and covers about 10 thousand square $\mathrm{km}$ surrounding Lake Onega and Zaonezhje peninsula (Figure 1, 2). The Paleoproterozoic succession in the Onega Synclinorium begins usually with Jatulian conglomerate, sandstone and dolomite marble, and includes a remarkable salt and gypsum horizon, discovered during drilling in 2008, at depth of about $2 \mathrm{~km}$, and finishes with Ludicovian black shungite-bearing schist, mafic lava and numerous sills, of age 2.2-1.8 Ga. The metamorphic grade these rocks are relatively low.

The synclinorium represents two separate folding episodes intersected by numerous NWtrending fault zones, parallel to the axial plane of the open later generation folds. The Zaonezhje peninsula sequence contains sandstones, carbonate and mafic volcanic rocks, shungite-bearing black schists, shungite-bearing aleurolites etc. The main types of bedrock are given in Table 4 and some more in [37]. Archean granite-gneisses are rich by $\mathrm{SiO}_{2}$ as well lydit, carbon-bearing silicate bedrock, but gneisses content verysmall amounts of microelements, while shungite-bearing black schists are more rich by $\mathrm{Cr}, \mathrm{Cu}, \mathrm{V}, \mathrm{Zn}$. As usual carbonate rocks have high concentrations of $\mathrm{MgO}$ and $\mathrm{CaO}$, higher $\mathrm{Ba}$, $\mathrm{Sr}$ and sometimes $\mathrm{Mn}$ content. More rich by metallic microelements are mafic and ultramafic volcanites, picrite-basalts, pyroxene diabase and also tuff-aleurite and shungite bearing rocks.

The synclinorium represents two separate folding episodes intersected by numerous NWtrending fault zones, parallel to the axial plane of the open later generation folds. The Zaonezhje peninsula sequence contains sandstones, carbonate and mafic volcanic rocks, shungite-bearing black schists, shungite-bearing aleurolites etc. The main types of bedrock are given in Table 4 and some more in [37]. Archean granite-gneiss (Table 4, No 1) is rich by $\mathrm{SiO}_{2}$, but contains small amounts of $\mathrm{CaO}$ and $\mathrm{MgO}$, and all trace elements. Typical andesite basalt (Table 4, No 2) contains some more $\mathrm{FeO}, \mathrm{F}_{2} \mathrm{O}_{3}, \mathrm{CaO}$ and $\mathrm{MgO}, \mathrm{Mn}, \mathrm{V}$ and $\mathrm{Zn}$, but 
other trace elements stay in the low level. Gabbro-dolerite (Table 4, No 3), picrite-basalt (Table 4, No 4) and pyroxene diabase (Table 4, No 5) contain more $\mathrm{FeO}, \mathrm{CaO}, \mathrm{MgO}$ and the most of needed for vegetation trace elements. Dolomite marble (Table 4, No 6 and No 7) are the main sources of the $\mathrm{Ca}$ and $\mathrm{Mg}$ for soils. In Onega Synclinorium are widely developed carbon (shungite)-bearing tuff-aleurolites (Table 4, No 8, shungite-bearing black schist (Table 4, No 9), shungite-bearing aleurolite (Table 4, No 10) and lydit (Table 4, No 11), which usually contain notable amounts of microelements: $\mathrm{Ba}, \mathrm{Co}, \mathrm{Cr}, \mathrm{Cu}, \mathrm{Mn}, \mathrm{Ni}, \mathrm{V}, \mathrm{Sr}$ and $\mathrm{Zn}$. In the places, where shungite-bearing rocks are near the surface, the soils are black color and sunlight keeps soils warm earlier than on the other soils. Especially it works on agricultural territories for getting crops of vegetables and potatoes.

\begin{tabular}{|l|c|c|c|c|c|c|c|c|c|c|c|}
\hline Component & 1 & 2 & 3 & 4 & 5 & 6 & 7 & 8 & 9 & 10 & 11 \\
\hline $\mathrm{SiO}_{2}$ & 71,38 & 57.20 & 48.08 & 43.54 & 47.49 & 11.78 & 17.90 & 40.28 & 29,11 & 53.92 & 93.89 \\
\hline $\mathrm{TiO}_{2}$ & 0.32 & 0.98 & 2.03 & 1.42 & 1.51 & 0.03 & 0.07 & 6.60 & 0.60 & 1.95 & 0.08 \\
\hline $\mathrm{Al}_{2} \mathrm{O}_{3}$ & 14.50 & 14.07 & 13.77 & 8.97 & 13.21 & 0.26 & 2.08 & 12.31 & 7.56 & 14.20 & 1.18 \\
\hline $\mathrm{Fe}_{2} \mathrm{O}_{3}$ & 1.33 & 1.21 & 3,38 & 1.74 & 2.46 & 0.12 & 1.52 & 2.58 & 6.23 & 1.93 & 1.08 \\
\hline $\mathrm{FeO}$ & 0.86 & 8.62 & 10.94 & 10.58 & 12.73 & 0 & 1.09 & 20.18 & 0 & 11.26 & 1.05 \\
\hline $\mathrm{MgO}$ & 1.47 & 4.09 & 5.97 & 18.22 & 7.74 & 20.33 & 15.80 & 4.11 & 1.36 & 3.58 & 0.03 \\
\hline $\mathrm{CaO}$ & 0.87 & 5.89 & 8.59 & 8.56 & 5,65 & 25.95 & 23.10 & 3.00 & 0.56 & 1.58 & 0.17 \\
\hline $\mathrm{Na}_{2} \mathrm{O}$ & 3.98 & 4.92 & 2.05 & 0.49 & 2.23 & 0.02 & 0.98 & 1.11 & 4.78 & 3.15 & 0.10 \\
\hline $\mathrm{K}_{2} \mathrm{O}$ & 2.85 & 0.63 & 1.19 & 0.15 & 0.40 & 0.04 & 0.16 & 0.10 & 0.25 & 1.53 & 0.52 \\
\hline $\mathrm{P}_{2} \mathrm{O}{ }_{5}$ & 0.12 & 0.19 & - & 0.18 & 0.17 & 0.12 & - & 0.20 & 0.02 & 0.30 & - \\
\hline $\mathrm{H}_{2} \mathrm{O}$ & 0.17 & 0.15 & 0.78 & 0.47 & 0.69 & 0.04 & - & 0.29 & 0.20 & 0.23 & 0.10 \\
\hline $\mathrm{LOI}$ & 1.78 & 1.54 & 3.83 & 5.43 & 5.89 & 41.06 & - & 8.54 & 51.44 & 5.83 & 1.36 \\
\hline $\mathrm{Ba}$ & - & - & 52 & 82 & 140 & 280 & 127 & 384 & 306 & 169 & 108 \\
\hline $\mathrm{Co}$ & - & 47 & 43 & 76 & 51 & 10 & 43 & 55 & 60 & 68 & 18 \\
\hline $\mathrm{Cr}$ & - & 34 & 230 & 710 & 130 & 8 & 62 & 314 & 142 & 274 & 299 \\
\hline $\mathrm{Cu}$ & - & 32 & 77 & 86 & 120 & 12 & 54 & 102 & 42 & 88 & 80 \\
\hline $\mathrm{Mn}$ & 225 & 1178 & 1472 & 1627 & 1395 & 124 & 1318 & 2325 & 620 & 1163 & 155 \\
\hline $\mathrm{Ni}$ & - & 63 & 70 & 290 & 75 & 12 & 96 & 201 & 184 & 182 & 49 \\
\hline $\mathrm{V}$ & - & 117 & 240 & 300 & 240 & 32 & 75 & 107 & 260 & 252 & 221 \\
\hline $\mathrm{Sr}$ & - & - & 170 & 98 & 97 & - & 319 & 103 & 120 & 187 & 84 \\
\hline $\mathrm{S}$ & - & - & - & 500 & 500 & 200 & - & - & 1700 & - & 10100 \\
\hline $\mathrm{Zn}$ & 24 & 80 & 65 & 100 & - & 48 & 56 & 122 & 184 & 103 & 140 \\
\hline
\end{tabular}

Table 4. Chemical analyses of main bedrock types of Onega synclinorium (macro-elements in weight $\%$, microelements - in ppm). Sample bedrock and place of sampling: 1 - graniit, $5 \mathrm{~km}$ to north from Kumsa River; 2 - andesite basalt, Kumsa River, Central Karelia; 3 - gabbro-dolerite, Unitsa Bay, Lake Onega; 4 - picrite-basalt, Rovkozero; 5 - pyroxene diabase, Radkola neck; 6 -dolomite marble, Pyalozero village; 7 - carbonate bedrock, Zaonezhje; 8 - shungite-bearing tuff-aleurolite, Nigrozero; 9 shungite-bearing schist, Mednyje Jamy village, Zaonezhje peninsula; 10 - shungite-bearing aleurolite, Nigrozero; 11 - lydit, Pustoshi 
In western limb of the Onega Synclinorium were studied soils in reduced and full profiles directly overlying on different bedrock, which shows that soils chemical composition is influenced by bedrock and Quaternary sediments composition (Table 5). In soil overlying shungite schist (carbon rich black schist)) the concentration of most elements is higher (Table 5 , No 15, 16) than in bedrock (Table 5, No 17). This indicates that the soil has been from the surrounding environment. About $70 \%$ of the Republic of Karelia is covered by granites, granite gneisses and migmatites of the Karelian Craton, which are rich by $\mathrm{Si}, \mathrm{Al}, \mathrm{Ca}, \mathrm{Na}, \mathrm{K}$, but contain very low concentrations of vital micronutrients. For example chromium concentrations in soil is some less than in bedrock, $\mathrm{Ni}, \mathrm{Cu}$ and $\mathrm{S}$ concentrations are reduced in soil lower horizons. Shungite, consisting of native carbon, is burned on ignition resulting in high weight losses (LOI). The direct influence of bedrock geochemistry on soils is less pronounced, when soil thickness over bedrock exceeds $0.5 \mathrm{~m}$. Most of soils are enriched in $\mathrm{SiO}_{2}, \mathrm{Fe}_{2} \mathrm{O}_{3}, \mathrm{Na}_{2} \mathrm{O}, \mathrm{K}_{2} \mathrm{O}$ and $\mathrm{Cr}$ from Quaternary soft sediments (Table 5).

\begin{tabular}{|c|c|c|c|c|c|c|c|c|c|c|c|c|c|c|}
\hline $\begin{array}{l}\text { Soil a } \\
\text { bedr }\end{array}$ & $\mathrm{O}_{2}$ & $\mathrm{Al}_{2} \mathrm{O}_{3}$ & $\mathrm{Fe}_{2} \mathrm{O}_{3}+\mathrm{FeO}$ & $\mathrm{MgO}$ & $\mathrm{CaO}$ & $\mathrm{Na}_{2} \mathrm{O}$ & $\mathrm{K}_{2} \mathrm{O}$ & LOI & $\mathrm{Ni}$ & $\mathrm{Co}$ & $\mathrm{Cr}$ & $\mathrm{Cu}$ & V & $\mathrm{Zn}$ \\
\hline & 23 & 4 & & 94 & 4 & 7 & 1.95 & 7 & $2 x$ & 8 & 27 & 8 & 39 & 16 \\
\hline 2.20 & .20 & .05 & & .06 & 1.56 & .97 & 1.86 & 1.38 & 32 & 8 & 41 & 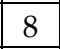 & 61 & 56 \\
\hline $\mathrm{G}$ & .38 & .50 & 2.19 & 47 & 8.87 & 3.98 & 2.85 & 1.78 & - & - & _ & - & - & 24 \\
\hline $4.0-$ & .97 & 3.19 & 1.50 & 0.99 & 1.22 & 0.70 & 0.57 & 74.05 & 24 & 0 & 0 & 6 & 28 & 112 \\
\hline 5 & .91 & .68 & & 25 & 3.12 & .23 & 1.24 & 31.82 & 71 & 16 & 34 & 72 & 34 & 104 \\
\hline $6-$ & .46 & 09 & & 28 & 3.09 & .42 & 1.48 & 21.08 & 55 & 16 & 137 & 144 & 224 & 72 \\
\hline 7.Pe & 41.26 & 5.28 & 11.64 & 26.8 & 3.79 & 0.07 & 0.02 & 8.46 & 1493 & 95 & 1680 & 32 & 168 & 803 \\
\hline 8.0 & 22.92 & 5.51 & 2.23 & 1.01 & 2.79 & 0.82 & 0.61 & 62.26 & 32 & 24 & 41 & 7 & 73 & 473 \\
\hline 9.4 & 59.29 & .99 & 5.62 & 1.80 & 2.50 & 2.79 & 1.23 & 12.71 & 79 & 24 & 89 & 24 & 162 & 264 \\
\hline 10.1 & 59.31 & .58 & & 97 & 2.10 & 74 & 32 & 13.56 & $2 \pi$ & 10 & 70 & 24 & & 225 \\
\hline 11.D & 49.20 & 2.94 & 10.45 & 9.75 & 5.39 & 3.42 & 0.80 & 4.20 & 134 & 47 & 226 & 32 & 221 & 104 \\
\hline 12. 0 & 14.22 & 2.10 & 4.16 & 11.7 & 14.5 & 0.43 & 0.42 & 51.35 & 24 & 16 & 27 & 16 & 34 & 136 \\
\hline 13.5 & 17.50 & 2.39 & 2.55 & 16.3 & 16.4 & 0.51 & 0.45 & 42.40 & 16 & 16 & 7 & 24 & 67 & 72 \\
\hline 14. N & 1.04 & 0.04 & 1.5 & 21.3 & 28.7 & 0.05 & 0.01 & 46.16 & 10 & 8 & 3 & 10 & 0 & 62 \\
\hline 15.0 & 69.29 & 9.05 & 6. & 1.56 & 1.15 & 0.90 & 1.99 & 8.58 & 71 & 8 & 96 & 88 & 302 & 145 \\
\hline 16.15 & 78.38 & 7.59 & 2. & 1.06 & 0.59 & 0.39 & 1.94 & 6.21 & 39 & 8 & 89 & 32 & 263 & 104 \\
\hline 7.Shungite & 59.80 & 3.8 & 1.39 & 0.60 & 0.21 & 0.05 & 1.55 & 31.86 & 40 & 8 & 102 & 40 & 225 & 16 \\
\hline
\end{tabular}

Table 5. Composition of reduced soil profiles on bedrocks in Onega Synclinorium (macro-elements and LOI in wt\%, micro-elements in ppm). Analyses made in laboratories Institute of Geology and Forest Research Institute, the Karelian Research Centre, Russian Academy of Sciences, Petrozavodsk, Russia. Soil sampling intervals in $\mathrm{cm}$ above bedrock (in bold): 1-3 - soils and Archean basement granite, $5 \mathrm{~km}$ to north from Kumsa River; 4-7 - soils and peridotite, Lake Konchozero: 8-11 - soil and gabbro-diabase, Hirvas village; 12-14 - soil and dolomite marble, Pyalozero village; 15-17 - soil and shungite schist, Zazhogino quarry, Zaonezhje peninsula, Lake Onega '

The Archean basement granites with soils were studied at northwestern limb of the Onega structure (Figure 2). Soils on Archean plagio-microcline granite (Table 5, No 3) are enriched 
by $\mathrm{SiO}_{2}, \mathrm{Fe}_{2} \mathrm{O}_{3}, \mathrm{Cr}, \mathrm{V}$ and $\mathrm{Zn}$ (Table 5, No 1-2). On the diabase, peridotite and marble the organic matter content in soil humus horizon is higher, up to $58-65 \%$, if counting differences in LOI, and $\mathrm{SiO}_{2}$ content is reduced to $59-14 \%$. Soils on peridotite (Table 5, No 7) have tendency of diminishing of elements in soils characterizes $\mathrm{Fe}, \mathrm{MgO}, \mathrm{CaO}, \mathrm{SiO}_{2}, \mathrm{Al}_{2} \mathrm{O}_{3}, \mathrm{Na}_{2} \mathrm{O}$, $\mathrm{K}_{2} \mathrm{O}, \mathrm{Ni}, \mathrm{Cr}, \mathrm{Cu}, \mathrm{V}, \mathrm{Co}$, but $\mathrm{S}$ and $\mathrm{Zn}$ show opposite tendency (Table 5, No 4-6). Soils on gabbro-diabase in Hirvas Village are more acid, contain $\mathrm{SiO}_{2} 59 \%$ in horizons 4-16 and 16-45 $\mathrm{cm}$, and less macro-element (Table 5, No 8-10) than bedrock (Table 5, No 11). Usually the element concentration diminishes gradually from bedrock to humus horizon: $\mathrm{A}_{2} \mathrm{O}_{3}, \mathrm{FeO}$, $\mathrm{MgO}, \mathrm{K}_{2} \mathrm{O}, \mathrm{V}, \mathrm{Cu}, \mathrm{S}$, but for $\mathrm{CaO}, \mathrm{Co}$ and $\mathrm{Zn}$ trend is opposite. $\mathrm{Zn}$ content grows from 104 ppm in bedrock to $473 \mathrm{ppm}$ in humus horizon (Table 5, No 8-11). Dolomite marble theoretical composition is $\mathrm{CaO} 30,4 \%, \mathrm{MgO} 21,7 \%, \mathrm{CO}_{2} 47.9 \%$, quite close to that is content of these elements in dolomite - $\mathrm{CaMg}\left(\mathrm{CO}_{3}\right)_{2}$ from Pyalozero Village (Table 5, No 14), in soil intervals only $\mathrm{MgO}$ and $\mathrm{CaO}$ are originated from bedrock, all other nutrients are added from Quaternary sediments (Table 5, No 12-13). It is likely that the abundance of $\mathrm{CaO}, \mathrm{MgO}$ and necessary micronutrients has resulted in the formation of a rich humus horizon, which is the basis for biodiversity. Phosphorus and sulphur are enriched in the humus horizon, due to the activity of animal and microbial life in the soil [58, 59], even if they are absent from the underlying bedrock, as for example, sulphur in the case of ultramafic magmatic rock peridotite (Table 5, No 4-7).

Quaternary sediments are not usually transported by ice over distance greater than $50 \mathrm{~km}$, and typically less than $5 \mathrm{~km}$. For the Onega Synclinorium this means, that favorable volcanic and carbonate rock influences are present everywhere, including fluvioglacial eskers and deltas. It must be noted that the most of bedrock contains notable amounts of $\mathrm{Mg}, \mathrm{Ca}, \mathrm{Na}$, $\mathrm{Fe}, \mathrm{Mn}$; mafic and ultramafic volcanic and intrusive rocks, shungite (carbon)-bearing aleurolites, in addition to essential metallic micronutrients such as $\mathrm{Co}, \mathrm{Cu}, \mathrm{Cr}, \mathrm{Ni}, \mathrm{V}, \mathrm{Zr}$ etc. About 800 vascular plants species have been recorded here as well as many rare plants from the Red Data Book for Fennoscandia [51] and Republic of Karelia [52], which is twice the number of vascular plant species (500) in the very large (5206 square $\mathrm{km}$ ) Vodlozero National Park, which is located at the same latitude and shares the climatic conditions, but which is situated $50 \mathrm{~km}$ to east, where thick Quaternary till and glaciofluvial deposits overlie Archean granites. To the east of the Vodlozero NP, in the Archangelsk Region of Russia is the Kenozero NP, which has similar physiographic conditions, but differs geologically due to the presence of Paleozoic carbonate rock and till derived from mixed sources, including granite from the Karelian Craton and local limestone. The number of vascular plant species present here is 534, of which 61 is listed into Red Book.

\section{Western and Northwestern Lake Ladoga area and the Valaam Archipelago}

The northeastern marginal zone of the Svecofennian Domain near Lake Ladoga is characterized by mantled granite gneiss domes. Narrow synclinal zones between basement domes comprise equivalents of the same Paleoproterozoic volcanic and sedimentary rocks, including dolomite marbles that occur in the Paanajärvi - Oulanka area and in the Onega 
Synclinorium. In the atlas of soils of the Republic of Karelia pH-values in the upper parts of soil horizons in the northwestern part of Lake Ladoga and in the central part of Onega Synclinorium are much higher $(\mathrm{pH}=3.5-5.0)$ than in Central Karelia, where bedrock consists mostly of granites and diorites, associated with $\mathrm{pH}$ values of 3.5 or less [38]. Due the small number of samples from the Paanajärvi National Park the influence of carbonate bedrock is not apparent in the Soil Atlas. Early Proterozoic Jatulian and Ludicovian rock units in the Svecofennian Domain in the Ladoga Zone are overlain by younger Kalevian sediments. The Precambrian basement is divided into separate blocks by numerous fault zones, which are reflected topographically as deep narrow valleys in which some northern species of mosses and lichens are found. The total number of vascular plant species in the area reaches 750, of which 550 are also present in the Valaam archipelago. The number of lichens and lichenicolous fungi exceeds 800 and 269 mosses have also been identified here [24, 52]. The main reason for such biodiversity is the extensive occurrence of carbonate and mafic volcanic rocks with their high concentrations of essential micro-nutrients.

The central part of Lake Ladoga coincides with the Mesoproterozoic sedimentary-volcanic bedrock of Ladoga Graben (aulacogene), which includes the thick dolerite sill outcropping on the islands of the Valaam Archipelago. Lake Ladoga is the largest freshwater body in Europe and shows a significant effect on microclimate. The coastline is much more favourable for agriculture and natural vegetation compared to terrain some 100-150 m above lake level, where snow melts some weeks in springtime and where autumn frosts occur several weeks earlier. The bedrock of the entire Valaam Archipelago is composed of a gabbro-dolerite sill, $220 \mathrm{~m}$ in thickness, associated with monzonite-quartz syenite, granite porphyry and granophyre [39]. A study of heavy metals and sulfur distribution in the soils of Valaam Archipelago has also recently been completed [40].

Comparison of the distribution of heavy metals (Table 6) in the main types of bedrock, namely gabbro-dolerite No 3211-6 and an average composite from monzonite - quartz syenites No 1488-3-12 [39] and soil horizons, shows good correlation between bedrock and soil composition (Table 6). The whole archipelago is formed from gabbro-dolerite and monzonite-syenite sill, while the surrounding lake is more than $100 \mathrm{~m}$ deep [61]. Therefore only small amounts of material would have been transported from the western and northwestern shores of the lake to the Valaam Island during glacial time. The local doleritic bedrock might therefore be expected to be enriched in microelements. Zinc is often concentrated in the upper parts of soil profiles (Table 5), while $\mathrm{Cr}, \mathrm{Cu}, \mathrm{Ni}$ and $\mathrm{V}$ abundances are close to those in bedrock. Only $\mathrm{Pb}$ shows some higher concentrations in soil horizons, but this may be due the small number of studied analyses in bedrock.

V. Koval'skij [13] gave next concentration intervals for normal life and development: Co - 730, Cu - 15-60, Zn - 30-70, Mn - 400-3000, Mo - 1,5-4, I - 2-40, B - 3-30, Sr - 0-10 [16]. At levels in excess of $500 \mathrm{ppm}$, zinc in soil interferes with the uptake of essential metals: Fe, Mn and B [3]. Anyway, so rare bedrock had significant influence to plant diversity. The Valaam Archipelago Nature Park has at least 590 vascular plant species in addition to introduced plant species, which grow here in great abundance. The finding of 61 Red Data Book species indicates that Valaam Archipelago Nature Park is of considerable floristic value. Some 
species, as Plantanthera chlorantha (Cust.) Reichenb., Potentilla neumanniania Reichenb., Corydalis intermedia (L.) Merát, Cotoneaster integerrimus Medik and Myosotis ramosissima Rockel ex Schult do not occur in other protected areas of Karelia [60]. The content of Ca in Valaam bedrock usually does not exceed $6-7 \%$ and is connected with other elements in hard mineral lattice. At weathering $\mathrm{Na}$ and $\mathrm{Ca}$ ions are carried out the first order, so in soil forms deficit of $\mathrm{Ca}$ and in archipelago does not grow beautiful plant Cypripedium calceolus $\mathrm{L}$.

\begin{tabular}{|l|c|c|c|c|c|c|c|c|c|c|c|c|}
\hline Bedrock or soil & $\mathrm{Cd}$ & $\mathrm{Co}$ & $\mathrm{Cr}$ & $\mathrm{Cu}$ & $\mathrm{Mn}$ & $\mathrm{Ni}$ & $\mathrm{Pb}$ & $\mathrm{V}$ & $\mathrm{S}$ & $\mathrm{Zn}$ & $\mathrm{FeO}+\mathrm{Fe}_{2} \mathrm{O}_{3}$ & $\mathrm{Fe}$ \\
\hline Gabbro-dolerite & - & 24 & 82 & 8 & 953 & 16 & - & 67 & - & 137 & $12.2 \%$ & - \\
\hline Monzonite-syenite & - & 20 & 34 & 12 & 973 & 9 & 16 & 54 & - & 166 & $10.9 \%$ & - \\
\hline Forest litter & 0.74 & 2.6 & 10 & 14 & 746 & 7.7 & 26 & - & 1240 & 170 & - & 11900 \\
\hline Soil beneath litter & 0.76 & 6.4 & 23 & 15 & 612 & 4.9 & 25 & - & 612 & 129 & - & 38000 \\
\hline
\end{tabular}

Table 6. Heavy metals contents in bedrock [39] and average abundances in forest litter and the uppermost mineral soil horizon beneath the litter [40] of Valaam Island. Sum Fe oxides in weight\%, microelements in ppm.

\section{Kilpisjärvi area, Finnish Lapland, NW Finland}

This area belongs geologically to the eastern marginal zone of the Scandinavian Caledonide nappes, far to the north of Arctic Circle (69-03'). The relief on the eastern slope of Scandinavian Mountain Ridge lies between $472 \mathrm{~m}$ (Lake Kilpisjärvi) and $1328 \mathrm{~m}$ above sea level, vegetation is typical for tundra zone, trees are represented with tundra birch, willows and some aspen trees on the southern slope of Saana Mountain (1029 m) near the Lake Kilpisjärvi, from coniferous grows only juniper, which may reach very high age, preliminary study shows, that more than 1000 years.

The oldest gneissose granodiorites, felsic, mafic and ultramafic volcanics and mica gneisses belong to the 2.7-2.8 Ga Neoarchean basement, which represents the autochthonous foreland to the Caledonian Orogen. osition, cratonised ago. This deformed and metamorphosed basement is unconformably overlain by Early Cambrian basal conglomerate, with silty and quartz-rich intercalations. Dolomitic marble is typical of the Jerta Nappe, which has been thrust somewhat to the southeast and forms a layer from 1-40 $\mathrm{m}$ thick, in some places strongly folded, and which may cover extensive parts of the hill slopes. Although there are 3-4 more nappes, with a total thickness of $450 \mathrm{~m}$ near the Kilpisjärvi Lake and up to $1250 \mathrm{~m}$ near the Halti Mountain [62-64], the most interesting rock unit with respect to the diversity vegetation is the dolomitic marble of the Jerta Nappe and the numerous small springs on the southern slope of Saana Mountain. The important influence of carbonate rocks on vegetation was first noted here by A. Pesola [42]. There are now three botanical protected areas that include all large dolomite outcrops in the Kilpisjärvi area: the Malla Strict Nature Reserve, 3000 ha, has been under protection since 1916, and was declared as a strict reserve in 1938, the Saana Protected Territory and the Annjalonji Protected Area were declared in 1988. Although there are many other hills with the same elevation and slope aspect, most of the rare and protected species are absent, where the bedrock is other than dolomite. 

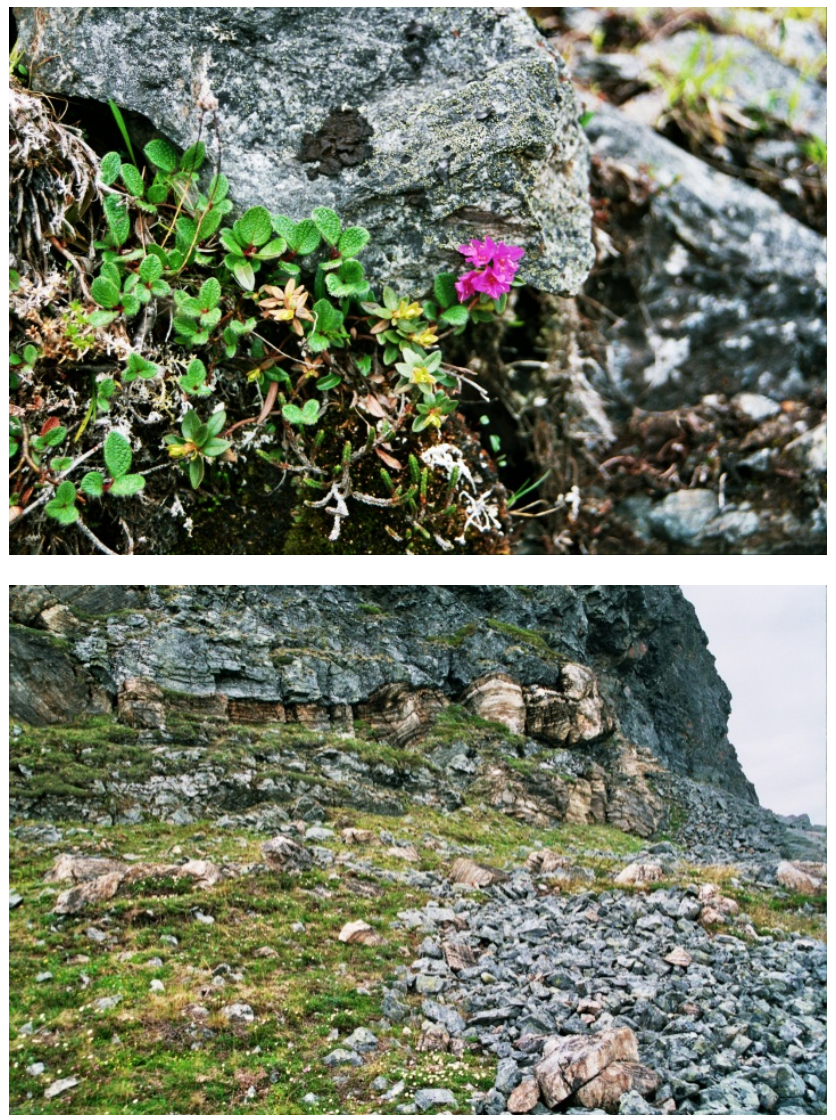

Figure 5. Rhododendron lapponicum L.flowering on the Paleozoic marbles of the Malla Strict Protected Territory (above). Slope of Pikku-Malla Hill with dolomite marble layer (below, light layer).

On the upper part of the Pikku-Malla fell these dolomite outcrops coincide with most of the rare plant finds: Erigeron acer L., E. uniflorus , Rhododendron lapponicum L., Polystichum lonchitis L., Pseudorchis albida (Fernald), Silene uralensis Rupr., Veronica fruticans Jacq. These and other protected rare and endangered vascular plant species are only found in the presence of carbonate rocks. During the flowering of Dryas octapetala L. the folded dolomite layers on the hill-slopes resemble natural flowerbeds. The influence of dolomite continues down slope and also in the spring waters. Numerous small springs discharge in the lower part of slopes and are associated with great floral diversity. In winter time the springs may be frozen but during the growing season, discharge flow rates of $0.2 \mathrm{l} / \mathrm{s}$ were recorded for Spring 1 and 0.1 1/s for Spring 2. Respective mineral components for Spring 1 and Spring 2 (where data are available)are: $\mathrm{Ca}(45$ and $47 \mathrm{~kg}), \mathrm{Mg}(18$ and22.2 kg), $\mathrm{K}(3.7$ and $1.8 \mathrm{~kg}), \mathrm{Na}$ (7.4 and $2.4 \mathrm{~kg}), \mathrm{Si}(9.5$ and $2.7 \mathrm{~kg}), \mathrm{S}(26.6$ and $23.8 \mathrm{~kg}), \mathrm{SO}^{4^{2-}}(71.9$ and $68.6 \mathrm{~kg}), \mathrm{NO}_{3}{ }^{-}(1.3$ and $0.3 \mathrm{~kg}), \mathrm{Cl}(4.3$ and $1.4 \mathrm{~kg}), \mathrm{Sr}(262$ and $180 \mathrm{~g}), \mathrm{Al}(55.2$ and $5.5 \mathrm{~g}), \mathrm{Ba}(23.2$ and $30.6 \mathrm{~g}), \mathrm{B}$ (7,3 and $4.8 \mathrm{~g}$ ), Li (2.4 and 3.4 g), Zn (6.1 and 3.1 g), Rb (3.3 and 2.1 g), Mo (0.95 and $2.1 \mathrm{~g}$ ), V 
(4.3 and $0.36 \mathrm{~g}), \mathrm{Cu}$ (3.1 and $0.86 \mathrm{~g}), \mathrm{U}$ (0.72 and $2.4 \mathrm{~g}), \mathrm{Co}(190 \mathrm{mg}), \mathrm{Bi}$ (63 and $110 \mathrm{mg}), \mathrm{Mn}$ (63 and $47 \mathrm{mg}$ ), As (252 mg, Spring 1 only), Sb (31.5 mg, Spring 1 only) and Th (95 and 16 $\mathrm{mg}$ ). Elements such as $\mathrm{Ag}, \mathrm{Be}, \mathrm{Cd}, \mathrm{Cr}, \mathrm{Ni}, \mathrm{P}, \mathrm{Pb}, \mathrm{Se}, \mathrm{Tl}, \mathrm{Fe}, \mathrm{Br}, \mathrm{F}$ have concentrations below detection limits. Water samples were analyzed at the Geological Survey of Finland. Because discharge from such springs is low, much of the water evaporates, leading to enrichment of essential elements in soils. On the soils developed over Precambrian granodiorite near these springs, some rare species were found, such as Saxifraga aizoides L., Pseudorchis albida (Fernald).

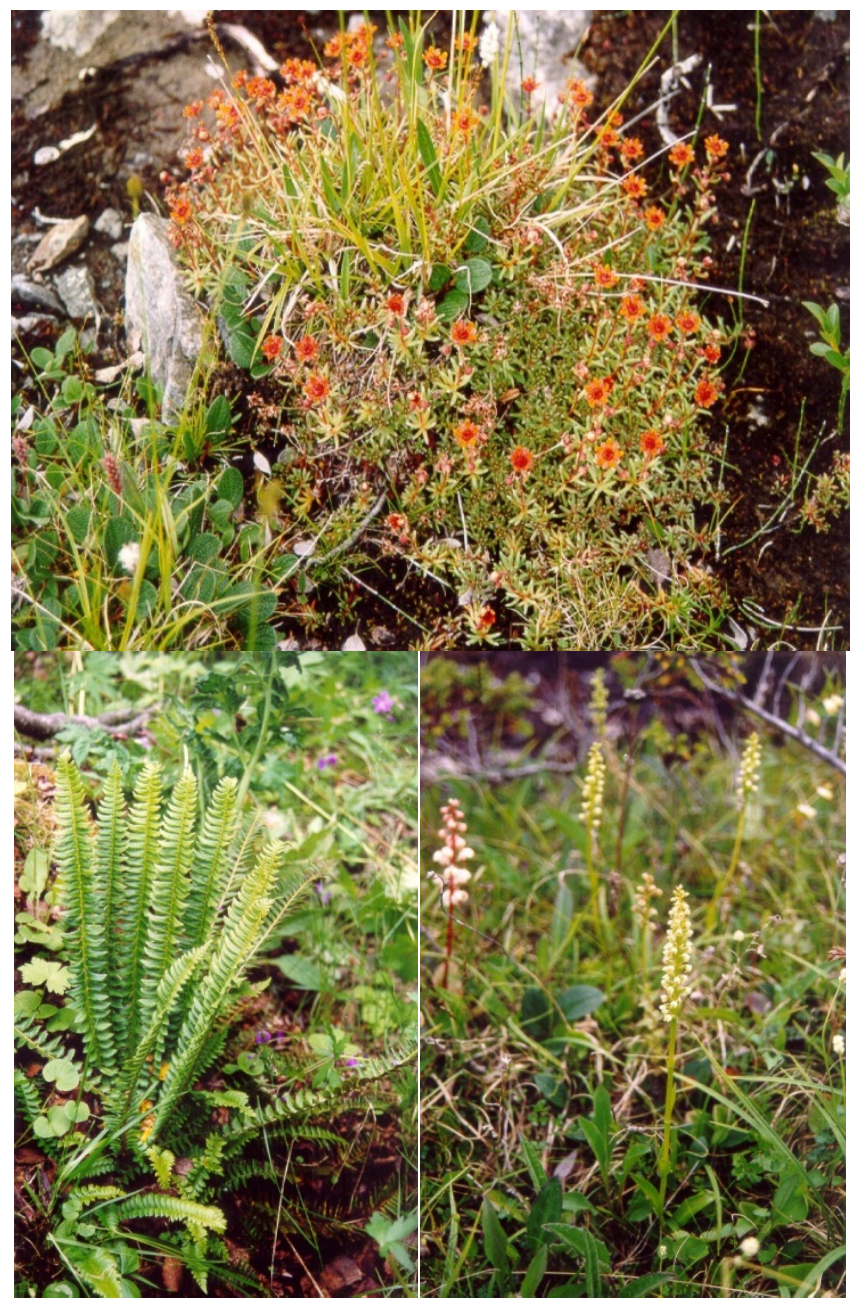

Figure 6. Saxifraga aizoides L. is flowering near the spring on the southern slope of Saana Mountain (above). Polystrichum lonchitis (L.) Roth is very rare plant in the Northern Finland, in Kilpisjärvi area is possible to meet it only on carbonate bedrock (below left). Another protected species Pseudorchis albida L. also likes Ca-rich soils (below right). 
About 470 vascular plants species have been recorded in the surroundings of Kilpisjärvi, most of them occurring on exposures of dolomitic marble. Pelitic Cambrian schists contains more microelements than quartzite and may be a more favored substrate for some species, including Dryas octapetala L.

\section{Areas surrounding Kevo Lake and Kevo Subarctic Research Station}

The bedrock of this area consists of Archean migmatites and gneisses, mostly hornbledebearing gneisses, which are divided into blocks with fault zones. Surficial deposits are wellsorted glaciofluvial gravels with clasts of granite and gneiss, which are thus rather poor sources of nutrients. Scots pine (P. sylvestris) is common in valleys and on hillslopes, but the Kevo area $\left(69^{\circ} 45^{\prime} \mathrm{N}\right)$ is some $150-200 \mathrm{~km}$ beyond the northern limit for spruce. The region is characterized by typical northern tundra species, and lacks rare species, which need more abundant macro- and micronutrients. Common species are Loiseleuria procumbens L., Phyllodoce caerulea (L.) Bab., Diphasiastrum alpinum L., Pinguicula vulgaris L. etc.

\section{Influence of bedrock and Quaternary sedimentary geochemistry on biodiversity in Estonia}

Estonia is located along the southern shore of the Gulf Finland and the Precambrian crystalline basement is everywhere covered by Ediacaran and Paleozoic sedimentary cover. The sedimentary cover together with basement is tilted gently southwards at a gradient of nearly $3 \mathrm{~m}$ per kilometre and its thickness increases from $125-140 \mathrm{~m}$ in the north to $600 \mathrm{~m}$ and more in southern and southwestern Estonia. Cambrian, Ordovician and Silurian bedrock are exposed in northern Estonia as east-west trending belts, whereas to the south these older sequences are covered by younger rocks. The resistant Ordovician limestone forms cliffs up to $56 \mathrm{~m}$ high, known as the North Estonian Klint (Figure 7).

During the last 400000 years, the region was repeatedly covered by ice during several glacial events, which advanced towards the south or southeast from the Scandinavian Mountains, transporting metamorphic and igneous rock material to Estonia. The Svecofennian domain is covered mostly by granites, migmatites and gneisses, with mafic rocks comprising only 3.5\% of till and boulder material [65]. Northern Estonia belongs to the zone of glacial erosion, where the thickness of Quaternary cover seldom exceeds 5-10 m, being in many places on alvars less than $1 \mathrm{~m}$ thick; eskers and glaciofluvial deltas may however, exceed $20 \mathrm{~m}$ in thickness. Southern Estonia is in contrast characterized by moderate sedimentary accumulation, with till cover in the Otepää and Haanja Uplands commonly exceeding $100 \mathrm{~m}$ and in the ancient buried valley of Abja a local maximum thickness of $207 \mathrm{~m}$ is attained. Local carbonate rock cobbles and pebbles predominate in the thick till sequences in central Estonia, but near the southern border the crystalline Fennoscandian bedrock becomes prevalent. These have a strong influence on soil composition, the Ca content in the humus horizon falling to $0.2 \%$ or less, while in carbonate bedrock $\mathrm{Ca}$ contents are between 1-8\%. The $\mathrm{Mg}$ content of sediments derived from carbonate rocks is usually $0.5-0.8 \%$, whereas in southern Estonia it is commonly less than 
$0.09 \%$. The minimum content of $\mathrm{Mn}$ in soils for healthy growth and development of plants is 400 ppm [16], but much of Estonia has Mn concentrations less than 230 ppm [49].

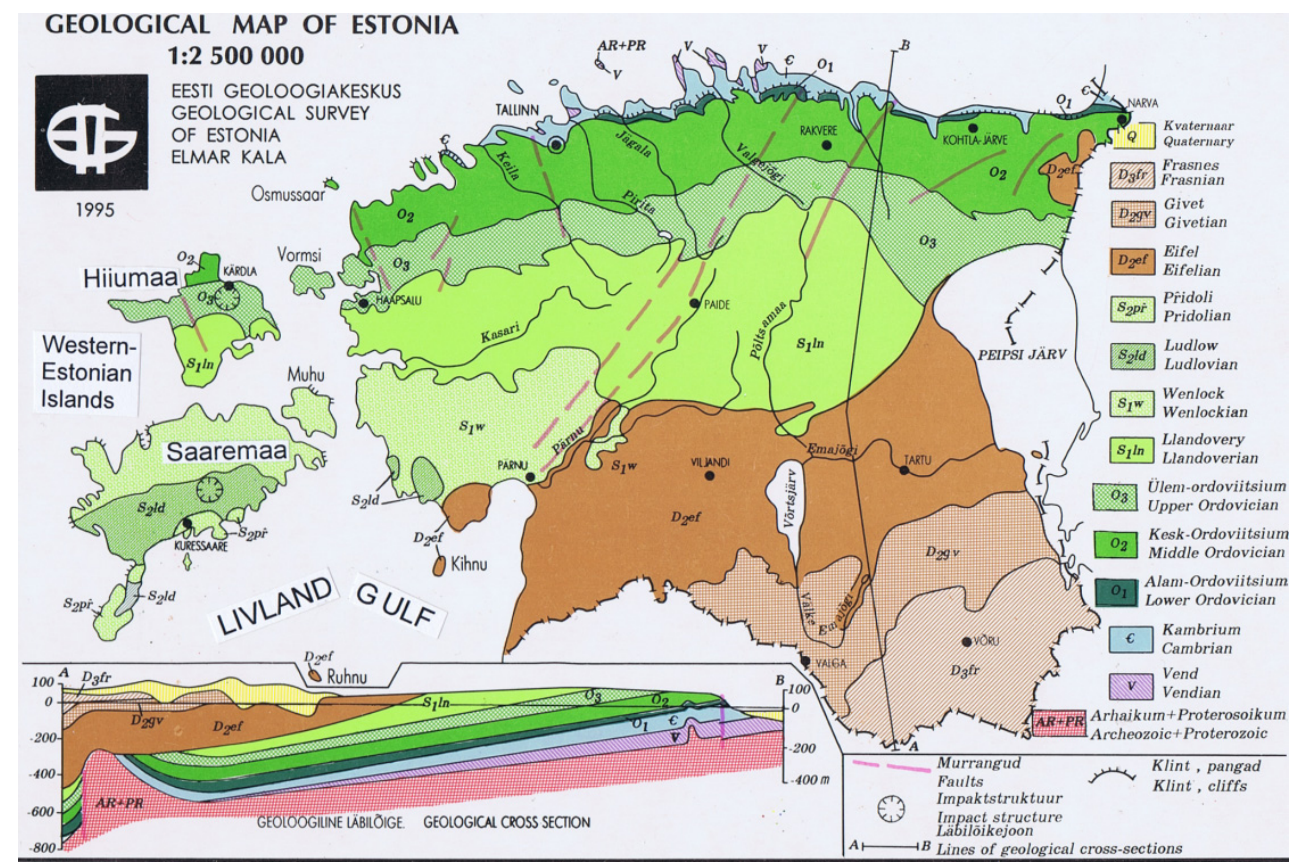

Figure 7. Geological map of Estonia. Compiled by E.Kala, 1995. Is published with permission of the Geological Survey of Estonia

Cambrian claystones and sandstones outcrop in the narrow zone between the klint and Baltic Sea shore. A number of micro- and macronutrients: $\mathrm{K}, \mathrm{Mg}, \mathrm{P}, \mathrm{B}, \mathrm{Co}, \mathrm{Cr}, \mathrm{Cu}, \mathrm{Ni}, \mathrm{V}$ and Zn have higher concentrations in these clays (Table 7, Es-1) than in carbonate rocks and sandstones. The influence of the clays is however restricted to this narrow zone. The Ordovician sequence begins with the Pakerordi Stage sandstone and the kerogenous darkbrown argillite horizon, which has a thickness of $7.7 \mathrm{~m}$ in northwestern Estonia, diminishing to about $2.0 \mathrm{~m}$ in northeastern Estonia. This argillite is notable for high concentrations of $\mathrm{U}$ (up to 400 ppm), K, As, B, Co, Cr, Cu, Hg, Mo, Ni, Pb, V and Zn (Table 7, Es-2). Soils are enriched in F, Mn. Mo, P, U and Y, but only within a narrow zone to the south, about $10 \mathrm{~km}$ wide, parallel to the klint [49].

The central and northern part of the Estonian mainland and the Western Islands are composed of Ordovician and Silurian carbonate rocks: marl, limestone and dolostone. Clayey limestone (Table 7, Es-17) contents some more $\mathrm{SiO}_{2}, \mathrm{Al}_{2} \mathrm{O}_{3}, \mathrm{MgO}, \mathrm{K}_{2} \mathrm{O}, \mathrm{Ba}, \mathrm{F}, \mathrm{Rb}$ and Sr. Limestone (Table 7, Es-3 and Es-9) contain maximum amount of $\mathrm{CaO}$ (50.51-52.67\%), some $\mathrm{SiO}_{2}, \mathrm{Al}_{2} \mathrm{O}_{3}, \mathrm{MgO}$, Mn, Sr, sometimes also F. Dolostone of Estonia (Table 7, Es-16, Es-18 and Es-4) usually contain some per cents impurities due the short distance from Fennoscandian Shield, as source of sandy material. $\mathrm{MgO}$ content in dolostone often exceeds $20 \%$, $\mathrm{CaO}$ content 28,87-30.87\%. 
Limestone and dolostone as bedrock and as pebbles and cobbles in gravel enrich all soils of Central Estonia and Western Estonia Islands with needed $\mathrm{Ca}$ and $\mathrm{Mg}$.

\begin{tabular}{|c|c|c|c|c|c|c|c|c|c|c|}
\hline Components & Es-1 & Es-2 & Es-3 & Es-16 & Es-9 & Es-17 & Es-18 & Es-4 & Es-15 & Es-5 \\
\hline $\mathrm{SiO}_{2}$ & 59.24 & 52.14 & 4.84 & 4.17 & 1,21 & 9.83 & 4.69 & 2.84 & 63.00 & 95.1 \\
\hline $\mathrm{TiO}_{2}$ & 0.88 & 0.76 & 0.077 & 0.084 & 0.022 & 0.089 & 0.062 & 0.041 & 0.20 & 0.23 \\
\hline $\mathrm{Al}_{2} \mathrm{O}_{3}$ & 17.38 & 13.15 & 1.10 & 1.20 & 1.25 & 2.45 & 0.88 & 0.75 & 18.04 & 1.81 \\
\hline $\mathrm{Fe}_{2} \mathrm{O}_{3}$ & 4.29 & 0.85 & 0.06 & 0.49 & 0.5 & 0.38 & 0.17 & 0.1 & 0.59 & 0.11 \\
\hline $\mathrm{FeO}$ & 2.60 & 3.02 & 0.44 & 2.58 & - & 0.38 & 0.30 & 0.35 & 0.14 & 1.33 \\
\hline $\mathrm{MgO}$ & 2.58 & 1.11 & 0.85 & 16.10 & 1.25 & 5.36 & 20.16 & 20.42 & 0.76 & 0.05 \\
\hline $\mathrm{CaO}$ & 0.84 & 0.22 & 50.51 & 30.87 & 52.67 & 40.79 & 28.87 & 29.35 & 0.29 & 0.047 \\
\hline $\mathrm{K}_{2} \mathrm{O}$ & 5.84 & 7.95 & 0.51 & 0.59 & 0.16 & 1.72 & 0.413 & 0.07 & 14.91 & 0.07 \\
\hline $\mathrm{Na}_{2} \mathrm{O}$ & 0.13 & 0.10 & 0.08 & 0.04 & $<0.03$ & 0.043 & 0.04 & 0.26 & 0.05 & 1.03 \\
\hline $\mathrm{P}_{2} \mathrm{O}_{5}$ & 0.31 & 0.13 & 0.42 & 0.232 & 0.043 & 0.015 & 0.026 & 0.012 & 0.077 & 0.022 \\
\hline $\mathrm{Cl}$ & 0.13 & 0.02 & 0.03 & 0.05 & 0.04 & 0.03 & 0.06 & 0.07 & 0.04 & 0.01 \\
\hline$S$ & 0.05 & 2.19 & 0.12 & 0.132 & 0.19 & 0.21 & 0.02 & 0.11 & 0.04 & 0.01 \\
\hline LOI & 4.95 & 19.91 & 40.39 & 42.49 & 42.61 & 37.70 & 44.02 & 45.33 & 1.37 & 0.29 \\
\hline As & 1.3 & 37 & $<1$ & $<1$ & 0.80 & $<1$ & $<1$ & $<1$ & 2.6 & $<3$ \\
\hline$B$ & 150 & 53 & 21 & - & 8.9 & - & - & 12 & 40 & 23 \\
\hline $\mathrm{Ba}$ & 420 & 379 & 29 & 41.6 & 20.09 & 46.88 & 31.92 & 14 & 119 & 147 \\
\hline $\mathrm{Cd}$ & $<1$ & $<1$ & $<1$ & 0.04 & $<5$ & 0.01 & 0.065 & $<1$ & $<1$ & $<1$ \\
\hline $\mathrm{Co}$ & 20 & 12 & 1.8 & 1.43 & $<3$ & 0.98 & 1.28 & 1.5 & 4.0 & 2.6 \\
\hline $\mathrm{Cr}$ & 78 & 80 & 9 & 9.68 & 8.25 & 7.28 & 10.67 & 9 & 9 & 31 \\
\hline $\mathrm{Cu}$ & 25 & 105 & 3 & 3.95 & 4.0 & 3.64 & 1.95 & $<4$ & 6 & 10 \\
\hline $\mathrm{F}$ & 1195 & 570 & 545 & 350 & $<100$ & 210 & 180 & $<100$ & 1200 & $<100$ \\
\hline $\mathrm{Hg}$ & $<0.01$ & 0.162 & $<0.01$ & $<10$ & - & $<10$ & $<10$ & $<0.01$ & 0.023 & $<0.01$ \\
\hline $\mathrm{Mn}$ & 320 & 158 & 460 & 2060 & 371.4 & 229 & 399 & 214 & 16 & 98 \\
\hline Mo & $<2$ & 56 & $<2$ & 0.41 & $<1$ & 0.57 & 0.31 & $<2$ & 1.0 & $<2$ \\
\hline $\mathrm{Ni}$ & 40 & 98 & 4 & 5.11 & 3.99 & 5.37 & 2.91 & 4 & 6 & 9 \\
\hline $\mathrm{Pb}$ & 11 & 77 & 5 & 2.84 & 13.94 & 3.54 & 1.63 & 4 & 9 & 7 \\
\hline $\mathrm{Rb}$ & 176 & 118 & 10 & 10.53 & 2.77 & 15.16 & 8.92 & 7 & 63 & 20 \\
\hline Se & $<4$ & 2.3 & $<6$ & $<1$ & 0.50 & $<1$ & $<1$ & $<3$ & $<3$ & $<4$ \\
\hline $\mathrm{Sn}$ & 3,9 & 3.2 & $<1$ & 0.13 & $<1$ & 0.25 & 0.14 & $<1$ & 7.2 & 0.73 \\
\hline $\mathrm{Sr}$ & 91 & 53 & 178 & 59.64 & 113.1 & 137.4 & 51.43 & 32 & 10 & 19 \\
\hline $\mathrm{V}$ & 109 & 509 & 9 & 14.00 & 3.40 & 9.60 & 20.8 & 11 & 14 & 11 \\
\hline $\mathrm{Zn}$ & 176 & 133 & 4.0 & 14.88 & 8.46 & 8.88 & 7.94 & 5 & 38 & 4 \\
\hline
\end{tabular}

Table 7. Macro- and micronutrients content in the main bedrock groups of Estonia (compiled after reference analyses $[47,48]$ macro-elements and LOI in weight \%, micro-components in ppm. Samples: Es-1 - claystone (clay), Ca2, Kunda; Es-2 - kerogenic argillite, O1, Tallinn; Es-3 - limestone, $\mathrm{O}_{2}$, Tallinn; Es-16 - dolostone $\mathrm{O}_{2}$, Maardu, Tallinn; Es-9 - limestone, $\mathrm{O}_{3}$, Vasalemma, Harjumaa; Es-17 - clayey limestone, S1, Valgu, Läänemaa; Es-18 - dolostone, S1, Anelema quarry, Pärnumaa; Es-4 - dolostone, $S_{1}$, Mündi quarry; Järvamaa; Es-15 - metabentonite, Kinnekulle bed, O3, Pääsküla, Tallinn; Es-5 sandstone, Middle Devonian, Suur-Taevaskoda outcrop, Ahja River. 
The entire region, except in areas of thick Quaternary cover, is enriched in Ca (1.25-6.06\%), $\mathrm{Mg}(0.44-2.12 \%)$, and sporadically in Mn and F. High fluorine contents are typical for felsic volcanic ash (metabentonite) layers (Table 7, Es-15). All other micronutrients in carbonate rocks are present in small concentrations (Table 7), which is also reflected in the compositions of soils developed on such bedrock. The central and northern part of the Estonian mainland and the Western Islands are composed of Ordovician and Silurian carbonate rocks: marl (clayey limestone), limestone and dolostone. Clayey limestone (Table 7, Es-17) contents some more $\mathrm{SiO}_{2}, \mathrm{Al}_{2} \mathrm{O}_{3}, \mathrm{MgO}, \mathrm{K}_{2} \mathrm{O}, \mathrm{Ba}, \mathrm{F}, \mathrm{Rb}$ and Sr. Limestone (Tabel Es-3 and Es-9) contain maximum amount of $\mathrm{CaO}$ (50.51-52.67\%), some $\mathrm{SiO}_{2}, \mathrm{Al}_{2} \mathrm{O}_{3}, \mathrm{MgO}, \mathrm{Mn}, \mathrm{Sr}$, in some places also F. Dolostones in Estonia (Table 7, Es-16, Es-18, Es-4) are usually secondary origin, so they contain some silicate minerals impurities due the short distance to Fennoscandian Shield. MgO content stays between 16.10 and 20.42\%, $\mathrm{CaO}-28.87-30.87 \%$, some higher is $\mathrm{Ba}, \mathrm{Sr}$, sometimes $\mathrm{Mn}$ and $\mathrm{F}$ concentrations. The entire region, except in areas of thick Quaternary cover, is enriched in Ca (1.25-6.06\%), Mg (0.44-2.12\%), and sporadically in $\mathrm{Mn}$ and F. High fluorine content is typical for felsic volcanic ash (metabentonite) layers (Table 7, Es-15). All other micronutrients in carbonate rocks are present in small concentrations (Table 7) as they are also in soils developed on such bedrock [49].

Southern Estonia is covered mostly by sandstones, which usually contain more than $95 \%$ quartz (Table 7, Es-5). As might be expected, concentrations of macro- and micronutrients in bedrock and Quaternary cover are low. The Sakala and Otepää Uplands contain material transported by ice from northern Estonia - mostly carbonate rocks - and from the Fennoscandian Shield - crystalline rock, mostly granite and migmatite. Many elements, such as $\mathrm{B}, \mathrm{Cd}, \mathrm{Co}, \mathrm{Cr}, \mathrm{Cu}, \mathrm{F}, \mathrm{Hg}, \mathrm{K}, \mathrm{Mo}, \mathrm{Na}, \mathrm{Ni}, \mathrm{Sn}, \mathrm{Sr}, \mathrm{U}, \mathrm{V}$ and $\mathrm{Zn}$, occur at very low concentrations in Fennoscandian bedrock and on the geochemical maps of the humus horizon of soil of Estonia they are distributed more evenly than elements derived from local bedrock. Because Estonian soils thus represent mixing of two components of differing composition, the influence of soils on vegetation is generally not so marked when compared with soils in Fennoscandia, where differences in vegetation are much greater. Nevertheless, Asplenium ruta-muraria L., A. septentrionale L., Equisetum hyemale L., E. x moorei Newman, etc grow only on the carbonate rocks of northwestern Estonia, near the Baltic Sea shore.

The most comprehensive listing of Estonian vascular plants and their distribution [50], has made it possible to assess how bedrock composition influences vegetation. The list records a total of 1353 plant species, about 50 of have uncertain occurrence, while some 700 are distributed more or less evenly, with no preference for bedrock type. A further 160 rare plant species likewise show no particular correlation with rock type, while 67 species are only found in proximity to the Baltic coast. There are 55 species that are endemic to carbonate bedrock and 35 species that grow exclusively on the sandstones of southern Estonia and 76 species that are completely absent from sandstone terrain. There are 137 species that occur predominantly on carbonate rocks, and compared to only 58 species that grow preferentially on sandstone.

The Western Estonian Islands emerged from the Baltic Sea later than the continental part of Estonia, which is also reflected in vegetation diversity: 46 vascular plant species are absent 
from Saaremaa, but another 50 species occur only on Saaremaa and have not been found on the mainland. The soil in Estonia has formed from two main sources, local sedimentary bedrock and crystalline material transported by glaciers from Fennoscandia. Geochemical maps of the humus horizon show that the concentrations of some elements - B, Ba, Cd, Co, $\mathrm{Cr}, \mathrm{K}, \mathrm{Na}, \mathrm{Ni}, \mathrm{Sn}, \mathrm{U}, \mathrm{Th}, \mathrm{V}, \mathrm{Zn}$ - show little or no influence from local bedrock. Conversely, abundances of $\mathrm{Ca}, \mathrm{Mg}$ and $\mathrm{F}$ in soil are correlated with bedrock composition, Mo and $\mathrm{P}$ concentrations in particular being closely associated with the kerogenic argillite near the North Estonian Klint; bedrock controls on $\mathrm{Fe}$ and $\mathrm{Hg}$ distribution is not so evident. In summary, material derived from the Fennoscandian Shield provided most of the following microelements in Estonian soils: B, Ba, Cd, Co, Cr, K, Na, Ni, Sn, U, Th, V and Zn. Recommended maximum permissible concentrations have been defined and legislated for most elements, but natural minimum concentrations should also be considered, below which there may be adverse influences on plant and animal health and life. For Mo this lower limit is $1.5 \mathrm{ppm}$ and for $\mathrm{Mn}$ it is $400 \mathrm{ppm}$, but normal ecological functions require a concentration of $3000 \mathrm{ppm}$ [16]. In Estonia the average Mo content is $2.5 \mathrm{ppm}$, but almost a third of the country has concentrations less than $1.2 \mathrm{ppm}$, Concentrations of $\mathrm{Mn}$ are between 75-2400 ppm, but half of the country records concentrations less than $400 \mathrm{ppm}$.

Southern Estonia is covered mostly by sandstones, which usually contain more than 95\% quartz (Table 7, Es-5). As Might be expected, concentrations of macro- and micronutrients in bedrock and Quaternary cover are low. The Sakala and Otepää Uplands contain material transported by ice from northern Estonia - mostly carbonate rocks - and from the Fennoscandian Shield - crystalline rock, mostly granite and migmatite. Many elements, such as $\mathrm{B}, \mathrm{Cd}, \mathrm{Co}, \mathrm{Cr}, \mathrm{Cu}, \mathrm{F}, \mathrm{Hg}, \mathrm{K}, \mathrm{Mo}, \mathrm{Na}, \mathrm{Ni}, \mathrm{Sn}, \mathrm{Sr}, \mathrm{U}, \mathrm{V}$ and $\mathrm{Zn}$, occur at very low concentration in Fennoscandian bedrock and on the geochemical maps of the humus horizon of soil of Estonia they are distributed more evenly than elements derived from local bedrock.

Comparison of average microelement concentrations in bedrock and humus horizons in Karelia, Russia (Precambrian Fennoscandian Shield) and Estonia (mainly Paleozoic sedimentary bedrock) clearly shows that soils on Precambrian bedrocks in Karelia contain much more microelements than sedimentary bedrock and soils on sedimentary bedrocks of Estonia (Table 8). It means that magmatic processes are bringing out from crust deeper levels enriched by many trace metals as $\mathrm{Cd}, \mathrm{Co}, \mathrm{Cr}, \mathrm{Cu}, \mathrm{Ni}, \mathrm{V}, \mathrm{Zn}$ and others. At studying geochemistry of soil humus horizon in Zaonežje peninsula in 2000 only in single probes $\mathrm{Cu}$ exceeded 2-3 times the highest permitted concentrations.

\begin{tabular}{|l|c|c|c|c|c|c|c|c|}
\hline Bedrock/ Elements & $\mathrm{Cd}$ & $\mathrm{Co}$ & $\mathrm{Cr}$ & $\mathrm{Cu}$ & $\mathrm{Mn}$ & $\mathrm{Ni}$ & $\mathrm{V}$ & $\mathrm{Zn}$ \\
\hline Karelian bedrock & 0.74 & 41 & 168 & 50 & 942 & 99 & 124 & 85 \\
\hline Estonian bedrock & 0.04 & 2.8 & 11.7 & 4.6 & 481 & 5.0 & 12.3 & 15.9 \\
\hline
\end{tabular}

Table 8. Comparison of average micronutrients content in bedrocks of Karelia Tables 3-5, Karelia, Russia and in bedrocks of Estonia (Table 7), excluded are bedrock analyses with extreemly high concentrations as peridotite in Karelia, clay and kerogenous argillite in Estonia 
The comparison shows clearly that soils on metamorphic or magmatic rocks of Karelia content much more trace elements, than sedimentary bedrocks in Estonia. Only Mn content in limestone may be reach the same level than in volcanic or intrusive bedrocks, all other elements have in magma concentrations 10-20 times higher.

\section{Discussion}

The geochemistry of bedrock and Quaternary sediments strongly influences soil nutrient content and at the same time biodiversity. Where beneficial nutrients are abundant in soils, southern species may spread far beyond their normal range, as in the case of Fragaria vesca L. and Rebes rubrum L. which are found near the Arctic Circle in the Paanajärvi National Park. The importance of micronutrients for wild animals and birds is also well known. In Northern Karelia in autumn, when blueberries are ripe, forest birds such as the capercaillie (Tetrao urgallus), black grouse (Tetrao tetrix L.) and even ducks tend to be selective in feeding, preferentially choosing plants growing on gabbroic and ultramafic rock, where berries are larger and contain more micronutrients. Larger mammals, including moose (Alces alces L.), brown bear (Ursus arctos L.), and reindeer (Rangifer tarandus L.) feed on mushrooms in summer and autumn time, because of the need for microelements. Animals that have access to all necessary nutrients are healthier and stronger, and hence better equipped to defend territory and offspring. Areas with abundant flowering plants are favored by insects, and therefore also by birds which then make nests in these places.

Geochemistry is therefore a valuable tool in assessing regional biodiversity in national parks, and in protection of species or areas of natural significance, or in designating areas for construction and urban development and agricultural use. A relationship between bedrock geochemistry and endemic diseases is established in many places [14, 66, 67, 68]. We must not forget that all life is built from the same building blocks, known as elements [3].

\section{Author details}

Ylo Joann Systra

Department of Mining, Chair of Applied Geology, Tallinn University of Technology, Tallinn, Estonia

\section{Acknowledgement}

Field work in Karelia was done in part with financial support from Ministry of the Environment of Finland. We acknowledge the support of the European Community Research Infrastructure Action under the FP6 "Structuring the European Research Area" Programme, LAPBIAT (RITA-CT-2006-025969) for studies in the Kilpisjärvi, Kevo and Oulanka areas in 2008-2009 and project No SF0140093s08 from the Estonian Ministry of Education and Research. This study is also part of the Estonian Science Foundation Grants No 7499 and No 8123. The author would like to thank Peter Sorjonen-Ward for correcting the English of the manuscript and numerous colleagues from different institutes of Karelian Research Center, who took part in the Finnish-Russian biodiversity project 1997-2000. 


\section{References}

[1] Mason BH (1966) Principles of Geochemistry. $3^{\text {rd }}$ edit., New York, John Wiley and Sons, Inc.329 p.

[2] Mason BH (1995) Geochemical Distribution of the Elements. In: New Encyclopedia Britannica, 15, Macropedia. pp. 939-950.

[3] Emsley, J (2003) Nature's Building Blocks, An A-Z. Guide to the Elements. Oxford University Press. 539 p.

[4] Albarède F (2009) Geochemistry. An Introduction. $2^{\text {nd }}$ ed. Cambridge University Press. $342 \mathrm{p}$.

[5] Bulakh AG (2002) General mineralogy. Sankt-Petersburg University Publisher. 356 p.(in Russian).

[6] Saukov AA (1975) Geochemistry. Nauka, Moscow. 480 p. (in Russian).

[7] Tayler RJ (1972) Origin of the Chemical Elements. $3^{\text {rd }}$ edition, London \& Winchester. 170 p.

[8] Tayler RJ (1995) Origin of the elements. In: The New Encyclopedia Britannica, 15, Macropedia. pp. 934-938.

[9] Thornton I (1983a) (ed) Applied Environmental Geochemistry. Academic Press, London). $501 \mathrm{p}$.

[10] Crounse RG, Pories WJ, Bray TB, Mauger RL (1983). Geochemistry and Man: Healt and Disease. 1. Essential Elements. In: Thornton I (ed.) Applied Environmental Geochemistry. Academic Press, London. pp. 267-308.

[11] Food and Nutrition III (1997) Tables of the chemical composition of food. Tallinn Technial University. 87 p.

[12] Barabanov, VF 1985 Geochemistry. Nedra, Leningrad. 423 p. (in Russian).

[13] Koval'skij, VV 1982 Geochemical environment and life. Moscow. 282 p. (in Russian).

[14] Thornton I (1983b) Geochemistry Applied to Agriculture. In: Thornton I (ed.) Applied Environmental Geochemistry, Academic Press. London. pp. 231-266.

[15] Emsley, J (1998) The Elements, 3rd ed. Oxford, Clarendon Press. 251 p.

[16] Trofimov VT, Ziling DG, Baraboshkina TA et al. (2000) Ecologic functions of the lithosphere. Moscow University Press. 432 p (in Russian).

[17] Kabata-Pendias A, Pendias H (2001) Trace Elements in Soils and Plants. $3^{\text {rd }}$ Edition. CRC Press, Boca Raton. 413 p.

[18] Merian E, Anke M, Ihnat M, Stoeppler M, (eds) (2004) Elements and their Compounds it the Environment. $2^{\text {nd }}$ Edition. Wiley-VCH. V. 1-3. 1773 p.

[19] Nies D.H. 2004. Essential and Toxic Effects of Elements on Microorganisms. In: Elements and their Compounds in the Environment. V.1, 2nd edit. Merian E. et al. (eds), pp 257304.Wiley-VCH Verlag $\mathrm{CmbH} \& \mathrm{Co.KGaA}$.

[20] Uthman E (2000) Elemental Composition of the Human body: http://www.abti.net/ABEBackup/Elemental_Composition_of_the Body.doc 27.02.2012.

[21] Plant JA, Raiswell R (1983) Principles of Environmental Geochemistry. In: Thornton I. (ed) Applied Environmental Geochemistry. Academic Press, London. pp.1-39. 
[22] Himeno S, Imura N (2002) Selenuim in Nutrion and Toxicology. In: Sankar B. (ed.). Heavy Metals in the Environment. New York, NY, USA: Marcel Dekker Inc.pp.587-629

[23] Webb JS (1983) Foreword. In: Thornton I (ed) Applied Environmental Geochemistry. Academic Press, London. pp. vii-viii.

[24] Gromtsev, A.N., Kitaev, S.P., Krutov, V.I. et al. (eds) (2003) Biotic diversity of Karelia: conditions of formation, communities and species. Russian Academy of Sciences, Karelian Research Centre, Petrozavodsk. 244 p.

[25] Korsman K, Koistinen T, Kohonen J, Wennerström M, Ekdahl E, Honkamo M, Idman H, Pekkala Y (eds.) (1997) Bedrock map of Finland 1:1 000 000. Geol. Survey of Finland, Espoo.

[26] Koistinen T, Stephens MB, Bogatshev V, Nordgulen $\varnothing$, Wennerström M, Korhonen J. (comps.) (2001) Geological map of Fennoscandian Shield 1:2 000000 . Espoo, Trondheim, Uppsala, Moscow. Geol surveys of Finland, Norway, Sweden, Ministry of Natural Resources, Russia, 2 sheets.

[27] Systra YJ (1987) Geological formations and tectonics of the Kukasozero-HankusjärviKuzhjärvi area. In: Early Precambrian of Karelia (geology, petrology, tectonics). Petrozavodsk, Karelian Branch Academy of Sciences USSR. pp.35-54 (in Russian).

[28] Systra YJ (1990) Structural evolution of the eastern part of Paanajärvi Synecline. In: Precambrian of Northern Karelia. Petrozavodsk, Karelian Research Center, Academy of Sciences USSR. pp. 40-61 (in Russian).

[29] Systra, YJ (1991) Tectonics of the Karelian Region. St. Petersburg, Nauka. 176 p. (in Russian).

[30] Systra YJ (1998a) Geological diversity: the main reason for the biodiversity of the Paanajärvi National Park. Oulanka Reports 19, 23-26.

[31] Systra Y (1998b) Vegetation map of the Oulanka-Paanajärvi national parks. In: Hautala H, Rautiainen L (eds) Oulanka-Paanajärvi. Acticmedia, Kuusamo.1 sheet.

[32] Systra, YJ (1998c) Role of geological-geomorphological factors in the formation of biodiversity in the Paanajärvi National Park. In: Biodiversity inventories and studies in the areas of Republic of Karelia bordering on Finland (express inform. materials). RAS, Karelian Research Center, Forest Research Institute. Krutov VI, Gromtsev AN (eds). Petrozavodsk. pp.27-32 (in Russian).

[33] Systra YJ (2000) Northern shore of Lake Ladoga. Geological characteristics of the territory. In: Biodiversity inventories and studies in Zaonezhskij peninsula and on the northern shore of Lake Ladoga (express inform. materials) Gromtsev AN, Krutov VI (eds) Petrozavodsk. pp. 194-197 (in Russian).

[34] Systra YJ (2003) Geological characteristics. In: Gromtsev, A.N., Kitaev, S.P., Krutov, V.I. et al. (eds.). 2003. Biotic diversity of Karelia: conditions of formation, communities and species. Petrozavodsk, Karelian Research Center of RAS. pp. 7-12

[35] Systra YJ (2004a) Main features of the Karelian region structures. In: Sharov, V.N. (ed.). Deep structure and seismicity of the Karelian region and its margins. pp.14-29. Karelian Research Centre, Russian Academy of Sciences, Petrozavodsk. 
[36] Systra YJ (2004b) Geological background for biodiversity in the eastern Fennoscandia, Estonia and Latvia. In: Parkes, M.A. Natural and Cultural Landscapes - The Geological Foundation, Royal Irish Academy, Dublin. pp. 73-76.

[37] Golubev AI, Systra YJ (2000) Zaonezhskij peninsula. Geological characteristics of the territory. In: Biodiversity inventories and studies in Zaonezhskij peninsula and on the northern shore of Lake Ladoga (express inform. materials) Gromtsev AN, Krutov VI (eds) Petrozavodsk. pp. 9-15 (in Russian).

[38] Fedorets NG, Bahmet, ON, Solodovnikov AN, Morozov AK (2008) Soils of Karelia: geochemistry atlas. Moscow, Nauka. 47 p (in Russian).

[39] Sviridenko LP, Svetov AP (2008) Valaam gabbro-dolerite sill and geodynamics of the Ladoga Lake trough. Petrozavodsk, Institute of Geology, Karelian Research Centre, Russian Academy of Sciences. 123 p. (in Russian).

[40] Shiltsova GV, Morozova RM, Litinski PJu (2008) Heavy metals and sulphur in Valaam archipelago soils. Petrozavodsk, Karelian Research Center, RAS, Forest Research Institute. 109 p. (in Russian with English conclusions and abstract).

[41] Kravchenko AV, Gnatiuk EP, Kuznetsov OL (2000) Distribution and Occurrence of Vascular Plants in Floristic Districts of Karelia. Petrozavodsk, Karelian Research Centre of RAS, Forest Research Institute, Institute of Biology. 76 pp.

[42] Pesola VA (1928) Kaltsiumkarbonaatti kasvimaantieteellisenä tekijänä Suomessa. Ann.Soc. "Vanamo" 9 (1), 246 pp. (in Finnish with summary: Calcium carbonate as a factor in the distribution of plants in Finland).

[43] Lehtinen M, Nurmi P, Rämö T (eds) (1998) Suomen kallioperä - 3000 vuosimiljoonaa. Helsinki, Geological Society of Finland. 373 p (in Finnish).

[44] Lehtinen M, Nurmi P, Rämö T (eds) (2005) Precambrian Geology of Finland: Key to the Evolution of the Fennoscandian Shield. Elsevier BV, Amsterdam. 736 p.

[45] Rasilainen K, Lahtinen R, Bornhorst TJ (2008) Chemical characteristics of Finnish Bedrock - 1:1 000000 scale bedrock map units. Geological Survey of Finland. Report of Investigations 171. Espoo. 94 p.

[46] Raukas A, Teedumäe A (eds.) (1997) Geology and mineral resources of Estonia. Tallinn, Estonian Academy Publishers. 436 p.

[47] Kiipli T, Batchelor RA, Bernal JP, Cowing Ch, Hagel-Brunnström M. et al. (2000) Seven sedimentary rock reference samples from Estonia. Oil Shale, 17, 3, 215-223.

[48] Kiipli T (2005) Database of the Chemical Quality of Carbonate Rocks. In: Yearbook of the Geological Survey of Estonia 2004, Tallinn, pp. 34-37 (in Estonian).

[49] Petersell V, Ressar H, Carlsson M, Mõttus V, Enel M, Mardla A, Täht K (1997). The Geochemical Atlas of The Humus Horizon of Estonian Soil. Tallinn-Uppsala: Geol. Survey of Estonia \& Geol.Survey of Sweden. 37 maps and Explanatory text. 75 p.

[50] Kukk T, Kull T (eds.) (2005) Atlas of the Estonian Flora. Tartu: Estonian University of Life Sciences. 527 pp.

[51] Kotiranta H, Uotila P, Sulkava S \& Peltonen S-L (eds) (1998) Red Data Book of East Fennoscandia. Ministry of Environment, Finnish Environment Institute \& Botanical Museum, Finnish Museum of Natural History, Helsinki. 351 p. 
[52] Red Book: Republic of Karelia (2007) Ministry of agriculture, fish husbandry and ecology the Republic of Karelia. Petrozavodsk, Karelia. 368 p. (in Russian)

[53] Atlas Karel'skoi ASSR (1989) Peihvasser VN (ed) Moscow. 40 p (in Russian).

[54] Söyrinki N, Saari V (1980) Die Flora im Nationalpark Oulanka, Nord-Finnland (The flora of Oulanka National Park, northern Finland). Acta Bot. Fennica 114. 150 p.

[55] Hautala A, Rautiainen L (1998) Oulanka - Paanajärvi. Photos: Hautala H, Rautiainen, L, texts: Systra Y, Viramo, J. Kuusamo, Articmedia. 144 p.

[56] Halonen P (1993) The lichen flora of the Paanajärvi National Park. Oulanka Reports 12, 45-54.

[57] Borodulina GS, Systra YJ (2001) Springs along the nature path in Paanajärvi National Park. Oulanka Reports 25, 5-8.

[58] Ponge J-F (2003) Humus forms in terrestrial ecosystems: a framework to biodiversity. Soil Biol.\& Biochemistry 35, 935-945.

[59] Lukina NV, Poljanskaja LM \& Orlova MA (2008) Nourishing regime of soils of the northern taiga forests. Moscow, Nauka. 342p. (in Russian).

[60] Kravchenko AV, Kuznetsov OL (2003) The role of protected areas in Karelia's border zone in the conservation of floristic biodiversity. In: Gromtsev, A.N., Kitaev, S.P., Krutov, V.I. et al. (eds.). 2003. Biotic diversity of Karelia: conditions of formation, communities and species. pp.69-76. Russian Academy of Sciences, Karelian Research Centre, Petrozavodsk.

[61] Ladoga Lake 2002) Atlas. Sankt-Peterburg. 129 p. (in Russian).

[62] Lehtovaara JJ (1994a) Geological map of Finland. Sheet 1823, Kilpisjärvi., PreQuaternary rocks, Geol.Survey of Finland.

[63] Lehtovaara JJ (1994b) Geological map of Finland, Sheet 1842 Halti, Pre-Quaternary rocks.Geolo. Survey of Finland.

[64] Lehtovaara JJ (1995) Kilpisjärven ja Haltin kartta-alueiden kallioperä. Summary: PreQuaternary rocks of the Kilpisjärvi and Halti map-sheet areas. Geol. Survey of Finland, Espoo 1995. $64 \mathrm{p}$.

[65] Pirrus E (2009) Big stones of Estonia. Story of large erratic boulders. Tallinn, Teaduste Akadeemia kirjastus (in Estonian, summary in English).

[66] Golovin A, Krinochkin L (2004) Geochemical specialization of bedrock and soils as indicator of regional geochemical endemicity. Geologija 48, 22-28, Vilnius.

[67] Gilder SSB (1964) The London Letter. Canad.Med.Ass.J. v. 91, 1081-1082.

[68] Thornton I, Farago ME, Thims CR et al (2008) Urban geochemistry: research strategies to assist risk assessment and remediation of brownfield sites in urban areas. Environ.Geochem. Health 30, 565-576. 